\title{
Martin Rohde
}

ORCID 0000-0001-9856-8654

Institut für Geschichtswissenschaften und Europäische Ethnologie

Leopold-Franzens-Universität (Innsbruck, Austria)

martin.rohde@,uibk.ac.at

\section{Local knowledge and amateur participation. Shevchenko Scientific Society, 1892-1914}

\begin{abstract}
This article discusses the possibilities which amateur participation offered to the young Shevchenko Scientific Society - limited to the description of the activities of this Society in the years 1892-1914.

The Society intended to develop rapidly into an academy of sciences in the Ukrainian language, but lacked the necessary resources. The existing network of Ukrainian associations in Eastern Galicia, which contributed to the development of scientific exchange, was helpful in achieving that status.

Before looking into the details of research agendas, the possibilities to use concepts of citizen science are measured for the context of the late 19 th and the early 20 th century.
\end{abstract}

\begin{tabular}{|c|c|c|c|c|c|}
\hline \multicolumn{2}{|c|}{$\begin{array}{l}\text { PUBLICATION } \\
\text { INFO }\end{array}$} & $\underbrace{\text { tistoriae }}_{\text {cientiarum }}$ & $\begin{array}{l}\text { e-ISSN 2543-702X } \\
\text { ISSN 2451-3202 }\end{array}$ & 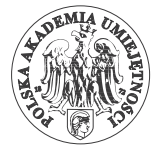 & $\begin{array}{c}\boldsymbol{\sigma} \\
\text { DIAMOND } \\
\text { OPEN ACCESS }\end{array}$ \\
\hline \multicolumn{6}{|c|}{$\begin{array}{l}\text { Rohde, Martin 2019: Local knowledge and amateur participation. Shevchenko Scientific Society, 1892-1914. } \\
\text { Studia Historiae Scientiarum 18, pp. 165-218, pp. 165-218. DOI: 10.4467/2543702XSHS.19.007.11013. }\end{array}$} \\
\hline \multicolumn{3}{|c|}{$\begin{array}{l}\text { RECEIVED: } 1.08 .2018 \\
\text { ACCEPTED: } 1.08 .2019 \\
\text { PUBLISHED ONLINE: } 15.11\end{array}$} & $\begin{array}{c}\text { ARCHIVE } \\
\text { POLICY } \\
\text { Green SHERPA / } \\
\text { RoMEO Colour }\end{array}$ & 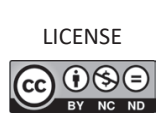 & $\begin{array}{l}\text { Crossref } \\
\text { Similarity Check } \\
\text { Powerod by ithenticato }\end{array}$ \\
\hline www & \multicolumn{5}{|c|}{ http://www.ejournals.eu/si/index.php/SHS/; http://pau.krakow.pl/Studia-Historiae-Scientiarum/ } \\
\hline
\end{tabular}


The relation between 'scientists' and 'amateurs' is problematized on the basis of biographical examples of engaged scientists and activists, especially Volodymyr Hnatiuk from the Ethnographic Commission and Stanislav Dnistrians'kyr from the Statistical Commission.

In order to understand the specific relations of Hnatiuk to his network of folklore collectors, their projects, aims and possibilities, Hnatiuk's research is contrasted with the statistical surveys initiated by Dnistrians'kyı̆.

Based on their archival documentation and published sources, these research projects are analyzed together with the different circumstances between the poles of "national science" and "local knowledge".

The article suggests that Ukrainian amateur researchers contributed intensely to the nation- and region-building in the multinational Empire.

Keywords: Shevchenko Scientific Society (Naukove tovarystvo imeni Shevchenka), citizen science, scientific community building, networks, Volodymyr Hnatiuk, Stanislav Dnistrians'ky̆, folklore, Habsburg census, Ukrainian science, 1892 $-1914$

\title{
Lokalna wiedza i uczestnictwo amatorów. Towarzystwo Naukowe im. Szewczenki w latach 1892-1914
}

\begin{abstract}
Abstrakt
W artykule omówiono, jakie możliwości oferowały amatorskie badania młodemu Towarzystwu Naukowemu im. Szewczenki działającemu w Galicji Wschodniej; ograniczono się do opisu działalności tego Towarzystwa w latach 1892-1914.

Towarzystwo zamierzało się szybko rozwinąć w ukraińską akademię nauk, ale brakowało mu do tego niezbędnych zasobów. Pomocą służyła istniejąca już sieć ukraińskich stowarzyszeń, która przyczyniła się do rozwoju wymiany naukowej.

Przed rozpatrzeniem szczegółów programów badawczych przeanalizowano możliwości wykorzystania koncepcji nauki
\end{abstract}


obywatelskiej w kontekście końca XIX i początku XX wieku. Przedstawiono relację między „naukowcami” a „,amatorami” na podstawie przykładów z biografii zaangażowanych naukowców i działaczy, zwłaszcza Wołodymyra Hnatiuka działającego w Komisji Etnograficznej i Stanisława Dniestrianskiego działającego w Komisji Statystycznej.

Aby zrozumieć specyficzne relacje łączące Hnatiuka z jego siecią kolekcjonerów folkloru, ich projektami, celami oraz możliwościami, badania Hnatiuka zostały porównane z badaniami statystycznymi zainicjowanymi przez Stanisława Dniestrianskiego.

W oparciu o dokumentację archiwalną i opublikowane źródła przeanalizowano niektóre projekty badawcze z perspektywy z jednej strony „nauki narodowej”, a z drugiej „wiedzy lokalnej”. Artykuł sugeruje, że ukraińscy badacze amatorzy intensywnie przyczynili się do budowania świadomości narodowej i regionalnej $\mathrm{w}$ wielonarodowym imperium.

Słowa kluczowe: Towarzystwo Naukowe im. Szewczenki, nauka obywatelska, budowanie spoteczności naukowej, sieci badawcze, Wotodymyr Hnatiuk, Stanistaw Dniestrianski, folklor, spis habsburski, nauka ukrainska, 1892-1914

\section{Introduction}

Shevchenko Scientific Society (Naukove tovarystvo imeni Shevchenka, further on NTSh), operating in East-Galician Lemberg (Pol.: Lwów, Ukr.: L'viv), pursued the goal of a rapid development into an official academy of science since its reform in 1892. While the previous literary organization contributed little to its formulated goal of supporting Ukrainian science, the young and energic historian Mykhailo Hrushevs'kyı (1866-1934) pushed the society towards its own research agendas. ${ }^{1}$ Scientific work was to be organized in sections and subordinated commissions, members - selected through criteria of scientific excellence, the collection of folklore texts and ethnographic objects for the library and a museum - which was yet to be built - and new periodicals

1 Hrushevs'ky1 came to Lemberg in 1894, became an editor of NTSh's journal in 1895 and its chairman in 1897. This paper cannot take on the actual reformation under Oleksandr Barvinskyı̌ and Hrushevs'kyı̀'s various initiatives to transform NTSh. For a detailed account of NTSh's academization and the development of specialized journals, cf. Zautseva 2006, pp. 40-180. 
were to contribute to the mobilization of Ukrainian academics. This reform therefore included transformation from an elitist to a more inclusive concept in terms of accepting new members, as the former restrictive rules were considered an obstacle for productive work. ${ }^{2}$ An explosion in the numbers of contributing scholars did not appear all of a sudden, as it became visible when the first journals started off. ${ }^{3}$ Due to low funding during the 1890 s and an increasing number of timeand cost-absorbing projects, leading members sought to delegate tasks to unpaid laypersons as well as profit from their knowledge. In order to discuss these inclusive transformations, the latest concepts of citizen science provide instructive suggestions.

Citizen science as a formative trend of the 21 st century knowledge production leads to new questions about the relation between the science and the public as well as the formation of scientific communities. Unpaid collaborators provide scientists with new possibilities, in both contemporary and historical practices, even though the scale of participants varies and communication as well as data processing work differently. Furthermore, the educational level narrowed the possible participation down to certain groups in Eastern Galicia. Latest discussions are drawing the attention closer to the intersection of science and citizenship, ${ }^{4}$ emphasizing the democratic potential of participation. This also concerns educational purposes, envisioning a type of schooling where "citizens actively collaborate in relation to accounting for future generations". ${ }^{5}$ For 19 th and early 20 th century histories of science, these ideas can serve as a heuristic stimulus, ${ }^{6}$ which helps to understand the formation of scholarly networks, the spread of scientific and non-scientific knowledge and motivations of groups to interact. There is already evidence for links between layperson participation in science and citizenship during the 19th century. ${ }^{7}$ This perspective has proven fruitful e.g. regarding collective actions against possible natural catastrophes. In Deborah Coen's case of earthquake observers in the Habsburg monar-

2 Barvins'ky1̆ 1892; Kupchyns'kyı̆ 2013.

3 Zaĭtseva 2006, pp. 133-136.

${ }^{4}$ Leach, Scoons, Wynne (eds.) 2005.

${ }^{5}$ Mueller, Tippins, Bryan 2012, p. 10.

${ }^{6}$ Shuttleworth 2017, p. 48.

7 Vetter 2012, p. 136. 
chy, she emphasized a multinational network managed by the imperial Earthquake Commission in the service of the state. ${ }^{8}$ NTSh, on the other hand, explicitly claimed to work for the greater good of the nation. ${ }^{9}$ Even though NTSh was not in direct opposition to the state, but profited tremendously from the relative freedom and financial support, ${ }^{10}$ it is difficult to speak of citizen science in a narrow, state-related sense. Indeed, the Habsburg Empire defined all of its subjects as citizens (Staatsangehörige), ${ }^{11}$ but this is not the dominant affiliation in the occurring network, defined through and working on language, culture and nation. While this paper will focus on Eastern Galicia, NTSh was especially designed to transcend state borders and initiate a dialogue between Ukrainian intellectual communities. Consequently, amateurs and experts from the Russian Empire contributed to the research as well. ${ }^{12}$ This point does not advocate for mutual exclusivity of the underlying identity concepts ${ }^{13}$ but for the integrative power of 'national science', showing interest in local affairs and providing their affiliates with access to a scholarly community. After all, even in a not directly state-related context, amateur participation was a relevant tool to build, shape and sustain a community. ${ }^{14}$ Hence, this article calls for a broad understanding of citizen science, which applies to the situation of multinational empires as well as national states and separate communities defined through language or other characteristics.

The peculiarities of the non-dominant Ukrainian nation in Galicia and its scientific community also contain problems for the understanding of the term '(professional) scientist'. McCray suggests to

use the terms 'professional scientist' and 'amateur scientist' with the recognition that the boundaries between and

${ }^{8}$ Coen 2013, pp. 141-162. For Maoist China, Fa-ti Fan has proposed a concept of citizen science shaped by "ideology, institutions, and functions of a state", that "reflected the intimate relationship between science and the macropolitics of modern state and society" (Fan 2012, p. 150). While (national) ideology was an important point for NTSh-leadership, it did not necessarily have to concern the participants.

9 Franko 1906; Kupchyns'kyı̌ 2013.

${ }^{10}$ Rohde 2019.

${ }^{11}$ For a discussion of this term cf. Gammerl 2010, pp. 73-76.

${ }^{12}$ Cf. Surman [Forthcoming].

13 Judson 2006; Zahra 2010; Hrytsak 2008-2009.

14 Coen 2013, especially pp. 69-101. 
the identities of these groups were indistinct and that they sometimes overlapped. ${ }^{15}$

This point on astronomy in the US during the 1950s has to be even more viable for NTSh during the given period, as 'getting paid' for scientific activity does not seem to be a suitable category for their members. The majority was not able to make a living predominantly by pursuing science, including many of the most distinguished scholars. They worked as teachers, lawyers or parliamentarians, a few also as clerics. The legal scholar Volodymyr Okhrymovych (1870-1931) served as head of Dnister insurance company, Ivan Franko's (1856-1916) main income was generated through literary and journalistic work. However, they did publish in their respective field of interest in multiple languages with international acknowledgement, as well as held doctorates. Since the number of chairs and other positions in the Ukrainian language at universities was rather limited, in the case of Franko also because of his former political activities, professional scientists in the narrow sense were rather an exception than the norm. ${ }^{16}$ NTSh provided several paid positions, such as a librarian, a secretary or a custodian of the museum, but these earnings were not enough to make a living. ${ }^{17}$ This specific situation of a scholarship in a subaltern community can help to question the binary conceptions of 'scientist' and 'amateur', as I will further argue based on the source material.

In order to discuss the relations of NTSh and amateurs in the given period, I will raise the following questions: Who were these amateurs and what benefits for the NTSh could be achieved through long-term relationships? How could amateurs contribute to scholarly nation- and

15 McCray 2006, p. 637; Coen (2013) also argues for her case that "[t]he line between expert and amateur was remarkably fluid in nineteenth-century seismology" (p. 9).

${ }^{16}$ For a detailed account on jobs and education of NTSh members 1910, cf. Khronika Naukovoho tovarystva imeny Shevchenka (further: Khronika) Nr. 45, 1911, pp. 16-30.

${ }_{17}$ Hnatiuk had several occupations within the NTSh, by which he could make a living, but he often complained about his difficult financial situation. This perspective does, of course, marginalize internationalist scientists as Ivan Pului or Ivan Horbachevs'kyr, who taught in German and Czech in Prague. Those are, however, notable exceptions. 
region-building? ${ }^{18}$ The first part of this paper investigates the problematic classification of amateurs in the given context, the renegotiations of this status in the long-term and the participation as a tool to get involved with the scholarly community. I shall illustrate these points using the scholarly biography of Volodymyr Hnatiuk (1871-1926), who began to work on folklore already as a pupil and became a respected authority in the field later on. As secretary of NTSh's ethnographic commission, he sustained a network of collectors of ethnographica and folklore, classified, edited and commented them for publication. In the respective case studies, I argue that local amateur researchers were especially relevant for studies in national borderlands. As shown by Patrice Dabrowski, the 'discovery' of the Carpathians as Galician borderlands was crucial for several identity building processes. ${ }^{19}$ Especially Polish and Ukrainian national movements contributed to the transformation of this landscape into a contested frontier, even after the collapse of the Habsburg Empire. ${ }^{20}$ The presented examples feature examples of the Hutsuls and the Boykos. Nowadays, both of these are identified as Ukrainian ethnic sub-groups. The Hutsuls are a distinct group of highlanders, the Hutsul region or hutsul'shchyna is located in the south-eastern part of the Carpathians. Of all Galician ethnic minorities, the Hutsuls were the most intensely studied and well-known also outside of Galicia, even as literary figures. ${ }^{21}$ Boykos, located in the Boyko region (boikivshchyna) in the middle Carpathians, were much less studied, until NTSh conducted an intense research expedition in $1904 .{ }^{22}$ Moreover, the territories outside of Galicia were an important point of reference. Transcarpathia, a term coined during the interwar period, was often referred to as "Hungarian Rus" in contemporary Ukrainian discourse, as these territories inhabited by Ruthenians were located in the Hungarian part of the Empire. The politics of Magyarization or (from the Ukrainian

${ }^{18}$ For the nexus of the respective disciplines and negotiation of identities cf. Baycroft, Hopkin (eds.) 2012; Göderle 2016; Stauter-Halsted 2001, pp. 97-114.

${ }^{19}$ Dabrowski 2005.

${ }^{20}$ Dabrowski 2008; 2013.

21 Makarska 2010.

22 Cf. below, section 2.3. A comparable example under different circumstances is the politicization of Alpine regions and the corresponding support for local research in Switzerland. Coen 2013, p. 78. 
perspective) denationalization fostered the wish to scientifically prove the ethnographic and linguistic belonging to the Ukrainian nation. ${ }^{23}$

The ethnographic research, usually understood as a highly successful enterprise, will then be contrasted with a largely forgotten crowd-sourcing project inspired by the Cisleithanian census. The census and its highly disputed category Umgangssprache (language of daily use), used since 1880, provoked intense debates; not only in the well-researched Czech case, ${ }^{24}$ but also in the Ukrainian political and scholarly community. Most likely inspired by Bohemian private counting initiatives in $1900 / 1901,{ }^{25}$ the statistical commission of NTSh initiated a similar project, combined with more complicated questions on interethnic relations and local politicization. This should allow a trustworthy revision of language and (implicitly understood) national statistics. While approximately 210 volunteers completed 290 questionnaires, there is not a single publication based directly on that material.

\section{2. "Long winter evenings" - liubyteli and experts}

I obtained the affection for folk poetry at home. My maternal grandfather $[\ldots]$ knew a tremendous mass of folk stories and gladly retold them to me, when I was around him. His wife Mariia, my grandmother, knew a large amount of songs. [...] Furthermore, the doors of our hut were almost never locked for the different people, which were sitting for a long time with us, like in a village casino, especially on Sundays, holidays and long winter evenings, and entertained with different stories, which I heard and learned with pleasure $[\ldots] \cdot{ }^{26}$

Volodymyr Hnatiuk used this childhood memory to explain his admiration for popular culture, which he did not associate with work, but

23 Tomashivs'kyǐ 1903.

${ }^{24}$ For an overview of the matter and the most relevant literature, cf. Hirschhausen 2012 .

${ }^{25}$ Czech activities in this matter were obviously received: Svoboda XIV, Nr. 37, $15^{\text {th }}$ September 1910, p. 2 ; Nr. 40, $6^{\text {th }}$ October 1910, p. 3.

${ }^{26}$ Hnatiuk 1916b, p. III. 
with family, sociability and conviviality. Thereby, he referred to emotional attachments to his field of research, varying drastically from the ideal of observers in Western Europe, who are prototypically "associated with a self-effacing, sober, emotionally disengaged expert". ${ }^{27}$ He devoted a considerable part of his life to collecting and editing folklore for publications, evolving from a child enjoying learning local tales to an internationally recognized scholar in the field of folkloristics. He became integrated in NTSh still during his studies, also receiving financial grants for his individual research. As secretary of the ethnographic commission of the NTSh and a co-editor of Etnohrafichny zubirnyk (Ethnographic Collection; further on EZ), he was responsible for expanding and maintaining a loose network of volunteering supporters. His imagination of these collectors explicitly reflected his feelings towards popular culture, as he addressed his first newspaper-request for transmittals to the "liubyteliiv of our folk literature". 28 The Ukrainian term liubytel denotes 'fancier' or 'enthusiast' as well as 'non-professional' in a positive connotation (in contrast to the more neutral 'amator', amateur). ${ }^{29}$ While the call appears to accentuate the former meaning, collecting folklore is presented both as a contribution to science and as a pleasant pastime during vacations on the countryside. ${ }^{30}$ Here, the call emphasizes the issue of locality, which seems essential, as some collectors worked almost exclusively in their hometowns. ${ }^{31}$ In this consideration, the emotionality regarding the subject of research is shared with the laypersons. I will come back to this point when taking a closer look at the question of how liubyteli were imagined.

During the early years of academization NTSh still lacked qualified contributors to its journals. The Ukrainian intelibentsia ${ }^{32}$ was small -

27 Coen 2013, p. 86. As some colleagues emphasize, emotionality seems to be a problem in contemporary Ukrainian scholarship (Petrenko 2016, p. 636); it would be a promising field for further investigations to trace this aspect historically.

28 Hnatiuk 1898.

29 N. N.2 1973, p. 562.

30 Hnatiuk 1898.

31 Cf. the case of Ivan Voloshyns'kyı̆ below, in section 3.2.

32 Vernacular Ukrainian term for the intelligentsia, usually meaning persons with higher education, who were affiliated with the national movement and especially its societies. However, the denoted group may vary in respective contexts. NTSh, for example, considers the 'village intelihentsia' as a distinct group. Cf. below, section 2.2. 
publishing in the organs of NTSh required linguistic and ideological compatibility. For example, (former) socialist scholars such as Ivan Franko and Mykha1lo Drahomanov (1841-1895) were not asked to contribute to the first issue of the Zapysky Naukovoho tovarystva imeny Shevchenka (further: Zapysky), the central periodical of the society. ${ }^{33}$ Mykhailo Hrushevs'kyl was appointed professor of the University of Lemberg in 1894. He took over the editorship of the Zapysky and functioned as president of NTSh from 1897 to 1913. To fill the increasing number of periodicals under his auspices, he increasingly turned to retired or young academics, as the number of contributors willing to publish ideologically-fitting papers in Ukrainian did not meet his expectations. For example, his students Stepan Tomashivs'kyı (1875-1930) and Stepan Rudnyts'kyı̌ (1877-1937) published literature reviews they wrote in class. ${ }^{34}$ While Franko became a steady contributor during the second half of the 1890s and started editing the major journals in cooperation with Hrushevs'kyr and Hnatiuk, the constantly increasing number of journals called not only for promotion of young researchers, but also for the inclusion of laypersons providing expertise on certain topics. The interest of NTSh in regional political and ethnographic affairs inspired the editors to request that kind of contributions.

A prominent way to distinct between amateur and professional scientist is graduation from related courses of study at a university, which is responsible for introducing standards. Folkloristics, Ethnology and Anthropology were not yet institutionalized in the Habsburg monarchy, as it was still being discussed what directions should be taken by these young disciplines. ${ }^{35}$ Consequently, scientific societies such as Towarzystwo Ludoznawcze (Ethnographic Society) in Lemberg, Verein für Österreichische Volkskunde (Society for Ethnography) in Vienna and NTSh were crucial for setting, maintaining and popularizing

33 Ză̌tseva 2006, p. 131.

34 Ibid., p. 136.

35 It was not until 1910 that ethnography and ethnology were institutionalized in Lemberg; even earlier than in Vienna (Tarnavs'kyı 2013). The world exhibition in Vienna, crown land exhibitions like the Galician Land Exhibition 1894 and several imperial publication projects, spear-headed by the well-known Kronprinzenwerk (Die österreichisch-ungarische Monarchie in Wort und Bild), supported the interest of imperial as well as national groups and societies in ethnography (Grieshofer 1998; Karpenko 2016; Scharr, Barth-Scalmani 2011). 
standards in the related disciplines and for the communities they addressed. These standards, however, varied according to the respective community and location. The imperial Volkskunde intended to mediate national differences by emphasizing similarities between national groups and subgroups. ${ }^{36}$ The respective disciplines in NTSh, on the other hand, were eager to scientifically justify a separate Ukrainian identity. ${ }^{37}$ Consequently, conceptions of 'professional' and 'amateur' have to be historicized individually for a respective scientific community ${ }^{38}$ as those categories were co-produced.

After the reform of 1892, the standing rules of NTSh formulated the goal "to foster and develop science and art in the Ukrainian-Ruthenian language, preserve and collect any monuments, antiques and scientific objects of Ukraina-Rus", as well as the collection of related material in and outside of Galicia, which was considered necessary to achieve this goal. ${ }^{39}$ As the following examples will show, there were generally two types of collectors, but with some intermediary positions.

\subsection{Volodymyr Hnatiuk}

Volodymyr Hnatiuk grew up in the small village of Velesniv/Weleśniów. When he was still a grammar school pupil, he collected songs and prepared them for publication in the Russophile journal Novyi Halychanyn. ${ }^{40}$ The Russophiles are no coherent national identity, but rather a conservative orientation of Galician-Ruthenians "looking at the existing Russian state as a potential protector and savior". ${ }^{11}$ While this episode illustrates the fact that national affiliations were not as clear and stable as often referred to, Hnatiuk reported later on that he did not consider the Russophile orientation as being as stigmatized as it was in the beginning of the $20^{\text {th }}$ century. ${ }^{42}$ While the Russophile movement lost more and more ground to the Ukrainian national movement since the last

${ }^{36}$ Stachel 2002.

${ }^{37}$ Cf. below, section 2.1 .

38 Vetter 2011, pp. 129-131.

39 Kupchyns'ky1 2013, pp. 60-61, quotation p. 60.

${ }^{40}$ Hnatiuk, Volodymyr, Avtobiobrafia 1900 r. IR NBUV, f. 170, N520, ark. 1.

${ }^{41}$ Zayarnyuk 2010, p. 118. For a detailed account of the Russophile movement in Galicia, cf. Wendland 2001.

${ }^{42}$ Hnatiuk 1916b, p. III. 
decade of the 19th century, the Russophiles remained a relevant political factor with support in several rural regions. ${ }^{43}$ After completing his middle school education at the Gymnasium in Stanislaviv/Stanisławów, Hnatiuk enrolled at the University of Lemberg, where he studied classical and Slavic philology, including language history and phonetics, as well as Ukrainian history, between 1894 and $1898 .{ }^{44}$ One of his professors was Antoni Kalina, the head of Towarzystwo Ludoznawcze at that time. This society was founded in 1895 and, even though the working language was Polish, it also included Ukrainian members. In his first semester, Hnatiuk handed Kalina a notebook containing some of his collected folk songs. Thereupon Kalina introduced him to Franko, who was a co-founder of the Towarzystwo. This connection turned out to be fruitful very soon, as Franko published materials and essays by Hnatiuk in his ethnographic and literary Journal Zhytie $i$ slovo. Furthermore, Franko invited him to be one of the first members of the newly founded ethnographic commission of NTSh. ${ }^{45}$ Hnatiuk took an unpaid two-month internship at NTSh, and then continued to work as a secretary for a minimal salary. When his salary was raised and he accumulated more positions, he served as an editor of several journals. Thereby, he was enabled to make a living, even though a poor one, without continuing his career as a schoolteacher that would have forced him to work outside of Lemberg. He considered this an altruistic decision justified by his love for science, popular culture and nation, as emphasized by his biographers. ${ }^{46}$

Galician-Ukrainian studies of folklore were influenced by the 1874 1875 two-volume folk song compilation that Mychailo Drahomanov and Volodymyr Antonovych prepared during their work in the South-Western branch of Imperial Russian Geographical Society in Kyiv. ${ }^{47}$ Through the work of Ivan Franko, who intensively corresponded with Drahomanov and edited the journals Zoria and Zhytie i slovo, which were dedicated to literature, ethnography and folklore, their comparative approach to folklore was disseminated among the Galician-Ukrainian intelihentsia already during the 1880s. ${ }^{48}$ Franko's and Hnatiuk's idea of editing EZ

\footnotetext{
43 Zayarnyuk 2010.

${ }^{44}$ Dashkevych (ed.) 1998, pp. 12, 17-18.

${ }^{45}$ Mushynka 2008.

46 Ivaniuta 2002; Mushynka 2012; Sheremeta 2003.

${ }^{47}$ Hnatiuk 1916a, p. 14; Dragomanov, Antonovich 1874-1875.

${ }^{48}$ Kolessa 2005, pp. 115-116.
} 
adapted this method, as they conceptualized it as coherent collections of certain text genres. By organizing the submitted materials directly Hnatiuk's work reflected this idea, as the documents in his archive at the Institute of Art Studies, Folklore and Ethnology in Kyiv clearly show. He usually received texts in notebooks or other forms of paper bundles. He cut them out to rearrange them in the designated order for the volume he was editing. ${ }^{49}$ Also the arrangements of texts in a certain volume were developed in a manner perceived as scientific and according to international standards and concepts. ${ }^{50}$

During the first half of the 19th century, Polish ethnographers considered Ruthenian folklore as an essential part of their own, referring to the Great Polish cultural identity. This inspired not only Ruthenians in the middle of the 19th century, who profited from existing structures of Polish folkloristics at that time, ${ }^{51}$ but also Hrushevs'kyl. Introducing the first issue of $E Z$, he regretted the lack of any steady institution responsible for the preservation of Ukrainian folklore during the last decades, since "ethnographic materials did not find themselves a shelter, got lost completely or were released on god's world in alien publishing houses". ${ }^{52}$ This point reflects his conception of the problems of the Ukrainian nation, as "the Polish nation-building strategy resembled the Great Russian one, for it also depended on restricting Ukrainian culture to a pre-national level of development and strove to exploit the Ukrainian ethnos as raw material for the construction of Polish national culture. ${ }^{, 53}$ His position was certainly not shared by all of Galician-Ukrainian intelihentsia, but for Hrushevs'kyı's followers, such as his young students like Hnatiuk, it was definitely influential, as Hrushevs'kyîs inclusion of ethnography in historiography inflicted a new dynamic in the study of popular culture. ${ }^{54}$

In 1895, Hnatiuk carried out his first research journey to the Ruthenian territories in Hungary, inspired and supported by Franko and Hrushevs'kyı̆. Until 1903, five more trips followed. He is not only

${ }^{49}$ Cf. the compilations of kolomyikey in IMFE, f. 28-3, spr. 424; spr. 425.

${ }^{50}$ Nakhlik, Sheremeta 2016, pp. 367-368.

51 Schwitin 2013.

52 EZ I, 1895, peredmova (unpag.).

53 Plokhy 2005, p. 89.

${ }^{54}$ Kuzelja 1930, pp. 173-174, 178-179. 
considered the first researcher of the region's folk prose; the overall quality of his recordings is considered to be "professional, that is to say, scientific, with complete preservation of the particularities of the vernacular, articulation and accents as well as lexical and morphological forms". ${ }^{55}$ These features were not treated with the same accuracy in the amateur recordings produced until then. He soon became an expert on the region, did not restrict his activities to folklore collections, as he conducted also ethnographic observations, worked on establishing a steady scholarly dialogue and inspired many of his colleagues, such as Franko, to study the region. ${ }^{56}$

The third volume of EZ, which appeared in 1897, was the first volume of Hnatiuk's "ethnographic materials from Hungarian Rus", comprising exclusively his own collections. The influence of Hrushevs'kyı and Franko is apparent from the dedication, describing them as "devotees of Ukrainian-Ruthenian science, friends and teachers of the youth". ${ }^{57} \mathrm{He}$ carefully edited the language, gave parallels for stories and motifs in other languages as well as adding translations of dialect words otherwise not understandable to his contemporaries. ${ }^{58}$ At the same time, he published several scientific papers, even though he was still a student. From 1896 he became a regular contributor to Zapysky, beginning with reviews. In the two years that followed, he placed two extensive papers in the journal. Other papers regarding his excursions to Transcarpathia were published in Franko's Zhytie $i$ slovo. ${ }^{59}$ His scholarly articles as well as his protest against the "denationalization" of Ruthenians in Hungary were intensely recognized in and outside of the Galician-Ukrainian community. ${ }^{60}$ Since 1900, Hnatiuk had been more and more included in the process of editing NTSh's journals. After his last field trip in 1903, he suffered from severe health conditions, holding him from further expeditions. Therefore, his compilations of folklore depended on material he had collected earlier and especially on texts submitted by others. ${ }^{61}$

55 Romanenchuk 1981, p. 6.

${ }^{56}$ Pan'kevych 1926.

${ }^{57}$ EZ III, 1897, p. [III].

${ }^{58}$ EZ III, 1897, pp. XIV-XX.

59 Mushynka 2012, pp. 50-52; Mushynka 2008.

${ }^{60}$ Nakhlik, Sheremeta 2016, p. 361.

${ }^{61}$ Hnatiuk 1916b, p. VI. 
Hnatiuk was constantly anxious to improve. Franko was an important mentor, but he also turned to Fedir Vovk (1847-1918), a well-known Ukrainian anthropologist and ethnologist working in Paris. Hnatiuk was curious about the expert's opinion in order to improve, especially regarding his first compilations. He developed a relationship of trust with Vovk, asking him for advice in any possible matter. He complained about not having access to a lot of specialist literature on folklore in Lemberg, and those works he found were not providing the methodological advices for professional documentation of the collected folklore he wished for. While being able to read in German and any Slavic language but Bulgarian, his linguistic repertoire lacked French and English. Beginning to teach himself French, he slowly was able to read publications Vovk recommended to him. ${ }^{62}$

Hnatiuk's early work shows an independent style of working, even though influenced by prominent Ukrainian humanities scholars and general issues of Ukrainian science. After his first excursions, he had to be considered an expert in terms of folkloristic field work. He achieved a reputation as a scientist through his publications in Zapysky, while his further work on preparing folklore compilations confirms this picture. While one might argue that this was no scientific task, categorizing and arranging the texts included interpretive steps based on linguistic and folkloristic knowledge. Hnatiuk was setting standards himself and provided the most systematic compilations of the respective genres.

\section{2 "Village intelihentsia"}

Finally, who are these local activists incorporated into NTSh's research? Most of the calls for submissions were directly addressed to the "village intelihentsia", namely teachers and clerics. Himka categorizes educated groups in the countryside not having to earn their income through agricultural work as (village) "notables". ${ }^{63}$ NTSh's conception goes a step further, limiting the group by their level of education mainly to teachers and clerics. Due to the prerequisites of the Habsburg monarchy's educational system, women were not part of this group and do not appear as an active part in the corpus of sources this paper is based

${ }^{62}$ Naulko, Rudenko, Franko (eds.) 2001, pp. 12, 16.

${ }^{63}$ Himka 1988, p. 106. 
on. For Habsburg ethnography in general, it was quite common to encourage teachers and clerics to collect all kinds of material and information during the given period. ${ }^{64}$ Himka describes a Josephinist habit of the clerics, meaning a dedication for community work outside the church. ${ }^{65}$ This was highly valued by the national movement, even though an unavoidable association with any of the prominent or less prominent concepts of identity was not implied. The specific situation of Galicia was shaped by a relatively high illiteracy rate, exceedingly so in the countryside. In the Ukrainian case, the Lemberg-based enlightenment society Prosvita tried to counter it through an extensive introduction of reading halls during the 1890s. The coordination was further improved through branches on the level of districts or respectively towns. ${ }^{66}$ Usually village priests and teachers managed the reading halls during their leisure time. The halls received the daily press and collected literary works as well as popular scientific publications and some - even though not complete - publications of NTSh. ${ }^{67}$ The so-called "village intelihentsia" can therefore be considered to be literate and well-educated, but is also characterized by good reachability, connection to the ideals of popular enlightenment and, due to the respective activities, was well-informed about local conditions. Clerics also had to perform other worldly tasks, which brought them in close contact to the local population and their situation, as they were e.g. asked to confirm poverty of a person or family in order for pupils or students to apply for respective grants. ${ }^{68}$ As these points illustrate, their position and their potential to support research was based on their location and the knowledge resulting from it.

${ }^{64}$ Kaindl 1903, p. 94.

${ }^{65}$ Himka 1988, p. 120.

${ }_{66}$ Prosvita began its work already in 1868, worked on several educational and popular scientific matters and formulated even scientific aims in the first statute. The establishment of the branches slowly began in the 1870s, while the first five reading halls were introduced in 1891. In 1900, there were 924 and in 1908 already 2048 in Galicia. Lozyns'kyı 1908. For a detailed account on reading halls in Galicia cf. Struve 2005.

${ }^{67}$ Cf. fn. 167.

${ }^{68}$ Dashkevych (ed.) 1998, pp. 12, 17-18. Priests were also requested to help without an existing connection to Prosvita, as Hnatiuk's reports on his travels to Transcarpathia prove, but it was not always that easy for him to find support. EZ III, 1897, p. XX. 
According to Jürgen Renn, local knowledge may "primarily serve to solve problems of human survival, such as food production, communication, healing, building and mobility", as well as producing identity. Clear distinctions are not always possible, for example when it comes to language following "purposes of communication" as well as "constitute and preserve cultural identity". ${ }^{9}$ While folklore fulfilled primarily cultural needs, it was not only of interest to scientists analyzing features of local identities, but also linguistic matters. For ethnographic studies, observations on fishing, farming and other forms of food production were highly relevant. ${ }^{70}$ But knowledge about local circumstances was also relevant for research processes. First, it was obviously crucial to find out who was able to sing folk songs or tell stories and anecdotes in a favorable way, i.e. most authentic for the local understanding. Researchers visiting from outside, of course, had to find out about suitable narrators and persuade them to invest their personal leisure time into slowly dictating the traditions - a skill they had to learn at first, according to Hnatiuk. ${ }^{71}$ The easiest way to do that was by mediation of local activists. In case of more distant excursions, letters of recommendation, written by a recognized member of the intellectual community, were helpful to gain the trust of others. Local intelihentsia also supported researchers frequently by other means, such as accommodation, information about interesting events (funfairs, weddings) or about craftsmen. Derived from NTSh's perception, it is therefore plausible to speak of local experts. ${ }^{72}$

The process of notation posed other problems for the respective groups. Getting the nuances of spoken texts in local dialects - like intonations varying from the standard - while only hearing it once certainly required the researcher to have a certain level of qualification. Hnatiuk himself pointed out that he would only be able to understand local dialects in Transcarpathia because he had learned them beforehand. ${ }^{73}$

${ }^{69}$ Renn 2012, p. 330.

${ }^{70}$ Dashkevych (ed.) 1998, pp. 31-36.

${ }^{71}$ Literaturno-Naukoyyz Vistnyk 1899, T. 8, kn. 12, pp. 176-178.

${ }^{72}$ Olga Linkiewicz (2016) describes the same necessity for local knowledge for Polish ethnologists in the interwar period, whereby the aspect of language seems even more relevant.

${ }^{73}$ Dashkevych (ed.) 1998, pp. 31-36. 
A local would not have this problem, but, if not connected to the scholarly community, rather had to learn the praxis of notation. This does concern especially the relation between local particularities and contemporary standard language. As Hnatiuk emphasized, the "school orthography" 74 had to be used, not etymological spelling, which was used by Hungarian Ruthenians and Galician Russophiles. This may have at least constituted an obstacle for older people not affiliated with the school sector. For example, as the statistical questionnaires of 1910 show, 'old' (etymological) spelling was still used by some priests. ${ }^{75}$ There is also a letter of a pupil of the 8th grade, productive collector of song texts, who wished to note also the corresponding melody, but did not know how. ${ }^{76}$ In general, melodies sent in were rather exceptional; ${ }^{77}$ they were rather recorded by professional ethnographers with a phonograph, such as Osyp Rozdol's'kyr (1872-1945) and Filaret Kolessa (1871-1947). ${ }^{78}$

Peter Finke emphasizes a clear distinction between "citizen science light", which essentially means the collection of data, dependent on evaluation and analysis of professional scientists, and "citizen science proper". The latter describes a tradition bearing all central characteristics of science, but operating independently from institutionalized science. $^{79}$ That differentiation is certainly inspired by issues of a lack of recognition of lay scientists in the 21 st century, whereas a strict understanding is problematic for the context of NTSh in late 19th and early 20th century. On the one hand, NTSh itself and its various projects can be considered as an alternative to science institutionalized by the state, mostly pursued in other languages, in the case of Galicia predominantly Polish. On the other hand, NTSh literally was the institution for science in the Ukrainian language during the given period, furnished

${ }^{74}$ Literaturno-Naukovyi Vistnyk 1899, T. 8, kn. 12, p. 176.

75 Cf. e.g. statistical data of Orelets', TsDIAL, f. 309, op. 1, spr. 2550, ark. 15; statistical data of Borshchovychi, ibid., ark. 19.

${ }^{76}$ Letter to the ethnographic commission by I. Valiuk, 1913, IMFE, f. 29-2, spr. 4.

${ }^{77}$ But not excluded, cf. description of the former archive of the ethnographic commission, IMFE, f. 29-5, spr. 478, ark. 80; Material collected by Ivan Saviak, IMFE, f. $29-3$, spr. 247.

${ }^{78}$ Dovhaliuk 2016; Kolessa 1907.

${ }^{79}$ Finke 2014, pp. 36-46. Finke has important objections against the predominance of top-down citizen science as promoted nowadays, as it would degrade the "underestimated knowledge of laypersons". 
with explicit interest in contribution by laypersons. In this more narrow sense, however, Finke's intervention inspires the question how local experts and amateur participators could contribute independently from NTSh ideology. The very conception of publications such as $E Z$ was a careful edition of collected folklore, arranged in a comparative manner, usually not accompanied by sophisticated analysis and individual interpretations. ${ }^{80}$ It rather meant an invitation to promote local popular culture, a concept which obviously sparked interest. Everyone capable of doing so could hand in the material he found in his environment. As long as quality criteria and the previously announced forms of text genres were matched, every participant had the chance of getting published. In this sense, it is plausible to speak of democratization.

Additionally, the commissioned work created a possibility for local experts to share their knowledge. One of Hnatiuk's supporters in Transcarpathia was Yuriy Zhatkovych, a priest in Stroine. He was asked by Hnatiuk to prepare an ethnographic work on the region. The first part appeared in the second volume of EZ, while the rest remained unpublished for a long time. The same model is valid for Ivan Franko's acquaintance Mykhailo Zubryts'kyı̆, whose affiliation with NTSh became much more intense. Both Zhatkovych and Zubryts'kyl were elected members of the ethnographic commission. ${ }^{81}$ They wrote on topics of their local expertise and in this way helped to solve the issue of scarcity of authors in the NTSh journals. Such contacts in the countryside were also highly valued information for other researchers interested in the regions, Ukrainians as well as non-Ukrainians. ${ }^{82}$ Networking therefore has to be considered one of the most important skills for field work and collections in the given period.

\subsection{Mykhailo Zubryts'kyi}

Mykhailo Zubryts'kyr (1856-1919) is an outstanding example for the significant role that Greek-Catholic clergy could play for local intellectual life. In the reception of his work, as Frank Sysyn recently summed

${ }^{80}$ Hnatiuk usually presented analytic papers in LNV, Zapysky or in Zbytie $i$ slovo. Exceptions are to be found in the later issues of EZ. For a bibliography of his printed works cf. Mushynka 1987.

81 EZ II, 1896, pp. 1-36; Myshanych 1992, p. 33; Mazurok 2010, pp. 126-132.

${ }^{82}$ Dashkevych (ed.) 1998, pp. 19-20, 53-54. 
up, it is always referred as "the interconnectedness of God's work and national work". ${ }^{83}$ Zubryts'kyı̆ was a friend of Franko ever since their common time at Drohobych/Drohobycz Gymnasium and got in touch with him again when he was serving in the military in Lemberg. ${ }^{84}$ When he studied to become a priest, he certainly disagreed with the large number of supporters of the Russophile movement around his fellow students, as he problematized in his autobiography. ${ }^{85}$

Zubryts'kyĭ began publishing primarily short miscellanea in Zoria in the second half of the 1880s, when Franko was still collaborating with the journal. Their cooperation continued, when Franko began to issue his Zhytie i slovo in 1894, featuring not only short submissions, but also longer ethnographic descriptions of Zubryts'kyr's home village, Kindrativ/Kondratów. From 1898, he regularly published in NTSh's periodicals and other volumes, predominantly in the Zapysky, EZ and Materials on Ukrainian-Ruthenian Ethnology (further MURE) ${ }^{86}$ Many of these works were commented editions of his ethnographic collections, but he also provided historical and economical accounts of Mshanets', the village where he worked as a priest since 1889 and served as head of the local Prosvita reading hall. ${ }^{87}$ However, his interactions with NTSh were not limited to publications or his rare visits to Lemberg. As an acquaintance of Franko, he was asked to support several excursions to the region. Not only did he host Franko and Hnatiuk on several occasions, ${ }^{88}$ but also the renowned expedition led by Fedir Vovk in 1904. During this undertaking, a lot of material on the region was gathered. Vovk concentrated on anthropometric measuring and photographs. Furthermore, ethnographic objects were collected for museums in Vienna, Lemberg and Petersburg. Songs were written down by the expedition members and one of them, Zenon Kuzelia (1882-1952), observed a wedding he described in detail in MURE $1908 .{ }^{89}$ Zubryts'kyr did not only show the researchers around, but mediated with the locals, referred them to

\footnotetext{
83 Sysyn 2012, p. 85.

${ }^{84}$ Hrytsak 2006, p. 257; Sysyn 2013.

85 Zubryts'kyı̆ 2016.

${ }^{86}$ Zubryts'kyı̆ (ed.) 2013; Iakymovych 2006, p. 146.

87 Sysyn 2013, p. 25; Zubryts'kyı̌ (ed.) 2016, pp. 299-314.

${ }^{88}$ Kyrchiv 2008, p. 377; Dashkevych (ed.) 1998, p. 60.

${ }^{89}$ Kuzelia 1908.
} 
priests of nearby villages and assisted them by other means. As this point shows, he did not play a passive role in this project, but contributed actively to the successful conduction of the research..$^{90}$ In 1904, he was made a 'real member' of NTSh, a degree awarded for scientific achievements and commitment to the society. This point has to be considered of explicit importance, which becomes evident in comparison with Kuzelia, who received the same honor only after completing his doctorate, while Zubryts'kyı̆ did not have one. ${ }^{91}$

What came first, the chicken or the egg? While the scientists' interest in the region was, of course, stimulated by ethnographic peculiarities of the Boykos, it has to be doubted that the popularity of Mshanets' certainly the most often researched Boyko-village by NTSh - was influenced only by this aspect. Zubryts'kyı's hospitality, communicated by Franko and therefore accessible to his colleagues, would have contributed to that condition as well. In this regard, the village priest played a major role with sustainable influence on the perception of his village and region, in scholarly as well as popular discourse. But was he considered equal to the Lemberg-based members?

In an essay Zubryts'kyl published in 1905 in LNV, he discussed the benefits of science for the public. He argued for the practical use of ethnographic information instead of pursuing science for the sake of itself.9 ${ }^{92}$ As Franko argued in his reaction, even though Zubryts'ky1 was a representative of NTSh, he was not conveying the position of the NTSh leaders. Franko pointed to the statutes of the society, which did not include any didactic mission, and openly considered the priest's views as provincial. ${ }^{93}$ Still, as he pointed out in LNV in 1906, he highly valued Zubryts'ky1's work. Even though he did not consider the anecdotes Zubryts'kyı̆ included in his research as scientifically valuable, they would provide a lively picture of his subject. ${ }^{94}$ The idea of Ukrainian science articulated by Franko was addressed to an international scientific community, which should recognize Ukrainians as a cultural nation. These issues of proving intellectual maturity and national

${ }^{90}$ Franko 1905b; Vovk 1908.

91 Sysyn 2013; Patsaŭ 2013.

92 Sysyn 2013, pp. 16-17.

93 Franko 1905a; Sysyn 2013, p. 17.

${ }^{94}$ Franko 1906. 
individuality were dominant topoi for NTSh until 1918, ${ }^{95}$ also reflected in Hrushevs'kyr's aforementioned conception of academization of NTSh. While it is true that NTSh gave Zubryts'ky1 the possibility to articulate opposing thoughts, they were followed by severe criticism of the journal's editor literally on the next page. Of course, the polemic should be relativized by the fact that NTSh was under severe attack from Ukrainian politicians for not engaging in popular education; that is the overall context of these articles. But again, Zubryts'kyı̌ had many possibilities to support his fields of interest and articulate his positions. He handed in the material he considered as valuable, prepared at his own discretion and therefore even published anecdotes Franko regarded as irrelevant for science.

NTSh gave Zubryts'kyı the opportunity to place his region on the mental map of Ukraine or respectively (Eastern) Galicia in the different conceptions he addressed. Based on his support for Vovk's anthropometric research, he could also secure the presence of Boykos in broad works on Ukrainian anthropology, as well as place ethnographic objects as exhibits in museums in Lemberg, Vienna and St. Petersburg. Those objects were not only sold by NTSh: the Museum für Volkskunde in Vienna asked Zubryts'kyı̌ directly for models of local buildings, which was mediated by Franko. ${ }^{96}$ In summary, Zubryts'ky̌ functioned as an intermediary between several spaces - village, region, nation, and empire. He was able to generate advantages for himself as well as for the place and the group he intended to represent.

\section{Collecting folklore}

When Hrushevs'kyı asked Vovk, who had been working and studying in Paris for more than a decade by that time, about his thoughts on the first issue of $E Z,{ }^{97}$ Vovk praised the journal as such, but severely criticized the attached research program. This program included a large amount of questions regarding folklore, ethnography, local law traditions and anthropology. The questions were very general and covered all possible

\footnotetext{
95 Rohde 2019.

96 Rechnung Zubryts'kyĭ, Archiv Museum für Volkskunde, Vienna.

${ }^{97}$ For his biography cf. Franko 2000.
} 
fields of interest. ${ }^{98}$ In Vovk's consideration, it was obviously very close to the program he had designed for the South-Western Branch of the Russian Geographic Society, issued in 1873. Compared to the state-ofthe-art recent West European and US works, it would have been completely outdated. Furthermore, the questions would not fulfill their task of stimulating researchers. For communication between laypersons and scientists, language is often considered to be the key point; the scientific language of the experts had to be "translated" into something their network could understand..${ }^{99}$ When it comes to ethnography, the problem is less about terms, but more about how to communicate what information is of interest for the researchers, as Vovk demonstrated by the example of a general question on wedding rituals:

They [the amateurs, M.R.] will describe the wedding for you, but only so that you know that at the wedding there are bridesmaids, bride's male attendants and a karavai [korovai in contemporary Ukrainian; bride cake, M.R.] - and that's it, but nobody will tell you what you really need, because it does not come to their mind that you would need it. I am sufficiently aware of that issue $[\ldots] .{ }^{100}$

Accordingly, a "need for mediation"101 with non-professional researchers was postulated. Vovk suggested much more detailed questionnaires for specific matters, while matters of ethnographic collections should have been separated from ethnological and anthropological works. Soon, this also manifested itself in terms of the periodicals issued by the commission. The MURE were designated to the scientific study of anthropology, while the EZ was to remain responsible for all kinds of folklore. ${ }^{102}$ In the first volume of MURE, issued in 1899, Vovk proposed a research program for collecting information on "Arts of life" (Vovk's term in parenthesis; Ukrainian: pobutova tekbnyka) featuring specialized sets of questions on hunting, fishing, cattle breeding,

${ }^{98}$ EZ I, 1895, pp. 1-16 (separate pagination).

99 Coen 2013, pp. 11-12.

100 N. N.3 2001, p. 111.

101 Coen 2013, p. 101.

102 To Vovk's disappointment, distinctions between these subjects were handled rather fluidly in NTSh. Cf. N. N.3 2001, pp. 111-112. 
grain cultivation, metallurgy or tanning. ${ }^{103}$ While Vovk initially planned to intensify this concept with further detailed programs, such as the one for weddings he intended to publish already for the first volume, misunderstandings between him and Hrushevs'kyl as well as financial limitations of the journal obstructed a more intense development of this kind of questionnaires. ${ }^{104}$ The program for weddings was circulated between interested scholars anyway and contributed to the special issue on wedding ceremonies in part two of MURE $1908 .{ }^{105}$ In the decade that followed, other specialized programs were designed, such as for collecting pysanky (traditionally designed Easter eggs), songs including melodies - or dialectal peculiarities. ${ }^{106}$

Vovk had strong objections to the integration of amateurs into anthropological research, he argued for example that anthropometric data would be outright worthless taken by a layperson, since that task would have to be fulfilled by a trained specialist. ${ }^{107} \mathrm{He}$ also dissuaded Hnatiuk from conducting anthropological research, as the latter was not trained in this field; if he would like to do so, Vovk suggested to visit him in Paris for a semester in order to learn the latest scientific methods. ${ }^{108}$ While amateurs were not categorically excluded from contributing ethnological or anthropological treatises or submitting related records, the emphasis of further programs was on folklore. Ivan Franko and Volodymyr Hnatiuk became responsible for the collecting, administering and publishing folklore; the latter, as the commission's secretary, was also responsible for organizational tasks. ${ }^{109}$ Together they were responsible for calls and questionnaires on folklore as well as the conceptualization of further volumes of EZ.

\subsection{Questionnaires and specialization}

The Chronicles (Khronika Naukovoho tovarystva imeny Shevchenka) and Literary-scientific herold (Literaturno-Naukovy̌ Vistnyk), a monthly

103 Vovk 1899.

104 Ibid., pp. 152-161.

105 Materiialy do ukraïns'ko-rus'kö̈ etnol'ogiï 10, 1908, part 2, pp. 1-150.

106 For a full account of such programs published and/or distributed by NTSh, cf. Hnatiuk 1916a, pp. 18-19.

107 N. N.3 2001, p. 104.

108 Dashkevych (ed.) 1998, p. 34.

109 Sapeliak 2000, pp. 24-34. 
revue, respectively their offprints, were a tool of communicating with the network of collectors apart from individual correspondence. The ethnographic commission not only posed special requests when new projects for $E Z$ were planned, but also reacted to frequent questions in a collective manner. The editors introduced their concept for $E Z$ already in their first call for submissions in LNV, in 1899. The upcoming volumes would be comprised of systematic arrangements of certain text genres, so that every volume would constitute a self-contained whole. The same text would also not be republished; thus contributors could orient themselves and would not conduct unnecessary work. By communicating their publishing plan the commission stimulated its supporters in advance to hand in texts of desired genres in time.

As it is apparent from Hnatiuk's editing, the methodology of recording was of essence. Every transcript sent in should contain at least the information who wrote it down, where, when and from whom. ${ }^{110}$ Even more than before, the editors emphasized that it would be necessary to write every text on a separate paper, only on one side. Every word should be written down as the narrator said it, without leaving anything out or adding anything; all specific features of dialects should be written down as accurately as possible, without changing anything into literary language. ${ }^{111}$ These aspects correspond to Hnatiuk's principles for the materials to have a scientific value. The descriptions, examples and instructions provided in the calls therefore also had a pedagogic value for prospective 'village scientists'.

In 1899, Franko and Hnatiuk asked for collections of folk legends, giving detailed descriptions of their most common topics with the request to turn to villagers talking about these. ${ }^{112}$ When the commission intended to edit three volumes of kolomy̌ky - two rhymed verses, integrated in folk music and folk dances - a pertinent call was issued. Obviously, the commission knew its network well already, since it turned directly to the network with the request to submit notebooks with earlier collections by parents and grandparents of contemporary activists. ${ }^{113}$ Further specialized calls requested local tales as well as historical

\footnotetext{
110 Literaturno-Naukovy̌ Vistnyk 1899, T. 8, kn. 12, p. 178.

111 Literaturno-Naukovyi Vistnyk 1902, T. 17, kn. 1, p. 78.

112 Literaturno-Nankovy̆ Vistnyk 1899, T. 8, kn. 12, pp. 176-178.

113 Literaturno-Naukovyž Vistnyk 1904, T. 26, kn. 6, p. 196.
} 
documents on robbers of the $16^{\text {th }}$ to $18^{\text {th }}$ century, funeral customs or local narrations on place names and historical figures. ${ }^{114}$ For the latter case, Hnatiuk prepared an extensive list of examples, which derived from his own collection, to illustrate what kind of material he was looking for in this more abstract request. At the same time, he provided patterns to show how these narrations should be written down.

To motivate prospective contributors, the commission continued to appeal to the liubyteli's altruism. Calls included the emphasis on free time of the village intelihentsia and peasants during long winters, but this formulation did not originate in any pejorative attitude about people living in the countryside; it was rather related to Hnatiuk's romantic ideas and childhood memories. In 1904, a reward system was successfully installed. If materials were published, the contributors would get a free copy of the related issue of EZ; if they contributed a lot of texts, they might receive other issues also. ${ }^{115}$ Apparently, this was a successful measure, since a summary in 1907 stated there was much more material than could be published due to financial reasons. ${ }^{116}$ Collecting seemed to be a never-ending story for Hnatiuk. During World War I, collections were lost and destroyed, so that Hnatiuk turned to the younger generation, which would have the "duty to save those collections with numerous new notations" of folklore. ${ }^{117}$ Even more than before, responsibility for cultural heritage was delegated. Some remaining letters of collectors prove not only their love for popular culture, but also that the questionnaires stimulated their interest and motivation. ${ }^{118}$ The calls had the possibility to influence the network with special requests, reconfiguring it according to changing needs and educating participants with scientifically approved patterns.

\subsection{Contributors, their interests and perspectives}

Due to the huge number of volunteers who contributed to the collection of the ethnographic commission, it is not possible to give detailed accounts in this article. Of the vast material, mostly preserved in IMFE,

\footnotetext{
114 Kbronika 1907, Nr. 31, pp. 28-31; Nr. 32, pp. 16-25; 1909, Nr. 39, pp. 37-39.

115 Khronika 1904, Nr. 20, p. 17.

116 Khronike 1907, Nr. 29, pp. 16-17.

117 Hnatiuk 1916a, p. 17.

118 Sapeliak 2000, p. 49.
} 
only a fraction has been published; many texts do not feature the name of their collectors. ${ }^{119}$ Accordingly, I will discuss the general base of interaction between the ethnographic commission and the volunteers, before considering examples of two of the most outstanding contributors.

In the school year 1909-1910, a historical-ethnographic circle was formed at Ukrainian-language Lemberg Academic Gymnasium. It was designed to attract pupils in the various disciplines and for one thing covered specialist lectures, by teachers of the school as well as by NTSh ethnographer and musicologist Filaret Kolessa. During spring and summer break, the pupils were instructed to collect objects for the National Museum and folklore for NTSh library. ${ }^{120}$ In November 1910, the circle sent a collection of 2,400 texts, foremost kolomyikey, to NTSh. In return, they asked to refer to the circle if the material was published and to receive a collection of NTSh's recent publications. ${ }^{121}$ Several other contributors also asked for certain issues of a periodical as a reward, even before this system was officially announced. This way, NTSh supported their contributors directly by following their interests, as they sometimes did not have the possibilities to buy them on their own. ${ }^{122}$ Yet another contributor hoped to be rewarded with other monographs published by NTSh. ${ }^{123}$

This is an example of an inspired teaching method and at the same time it underlines the mutual cooperation between Ukrainian institutions in Lemberg. Since participation was optional, it was either the subject that attracted pupils or the motivation by the teacher Aleksii Sushko, so that the pupils devoted their holiday time to this research. Ivan Pankevych (1887-1956) provides a suitable long-term example of a person successfully promoting young scholars. He became acquainted with NTSh already as a pupil of a Polish gymnasium in Lemberg. When he was preparing a talk on Transcarpathia, where he was born,

119 Documented in the inventory of the former archive of Ethnographic Commission, IMFE, f. 29-5, spr. 476. Hanna Sokil (2011) delivered the most detailed account on Ukrainian folklore in Galicia and covers more of the lesser-known names.

${ }^{120}$ Zvit dyrektsyii ts. k. akademichnoii himnazyii u L'vovi za shkil'nyı̆ rik 1909/1910, pp. 51-52.

121 TsDIAL, f. 309, op. 1, spr. 747, Letter to the executive board, 1910.

122 Sapeliak 2000, pp. 47-49.

${ }^{123}$ IMFE, f. 29-2, spr. 3, Letter to the ethnographic commission by T. Kuzyshyn, 1911. 
he regularly worked in the library of NTSh. There he also met several of its affiliates. The most influential acquaintance, as he wrote in his autobiography, was Volodymyr Hnatiuk. He wrote down folklore in the village where he was born, as well as in the surrounding area. The first pieces were published already in 1907, in EZ. He stayed in contact with NTSh during his studies in Lemberg and Vienna, and was made a real member in 1923. In the interwar period, he worked as an organizer of a national intellectual movement in Uzhhorod (then in Czechoslovakia), editing the journal Scientific Collection of Prosvita-Society in Uzhhorod (1923-1938). His works on dialectology and ethnography made him one of the most important researchers of the region. Early participation and motivation by and with NTSh sparked his interest into pursuing a scholarly career, following the footsteps of Hnatiuk. ${ }^{124}$ However, collectors without scientific ambitions were also dedicated to this task.

Bohdan Zaklyns'kyr (1886-1946) was born in Stanislaviv/Stanisławów (today: Ivano-Frankivs'k) in 1886. His family was well-known for its involvement in the Ukrainian national movement and their regional pedagogical work. His father, Roman, was a gymnasium teacher and also conducted ethnographic research. Bohdan Zaklyns'kyl studied at the teacher seminar in the city and graduated as an elementary school teacher in 1909. Between 1909 and 1913, he taught in several villages of Kosiv district. ${ }^{125}$ His motivation to collect originated in the almost endless amount of folklore. As he explained, after weddings in a village, people would "sing kolomyrky all night long, and all are new every time". There would simply be not enough specialists for this task, therefore "everyone who just has the possibility should take part in that, such as village priests, teachers, students, and even more enlightened villagers." ${ }^{126}$ His national romantic motivation is also reflected by the notebooks he handed in, sometimes with a big portrait of the national poet Shevchenko on the front, sometimes with portraits of many other Ukrainian writers or an included quotation of the national poet as a prefixed motto. ${ }^{127}$

124 Mushynka 2001, pp. 79-90.

125 Kas'kiv 1998.

126 IMFE, f. 28-3, spr. 178, ark. 3, Oral literature, collected by Bohdan Zaklyns'ky̆.

${ }^{127}$ IMFE, f. 29-3, spr. 85a, Zaklyns'ky1̆, B., Etnohrafiia; IMFE, f. 29-3, spr. 82-84, Baiky, etc. written down by Bohdan Zaklyns'kyı̆; IMFE, f. 29-3, spr. 79, Folk songs, written down by B. Zaklyns'kyı and others. 
He also inspired his family members as well as other acquaintances to leave him collections to submit them to NTSh, including material his father and others collected in $1874 .{ }^{128}$ Some of the latter material was also published. ${ }^{129}$ The personal notes he handed in started around 1904. When Zaklyns'kyĭ was still a student, he sent his first collections to Ivan Franko. He received a long answer, which he did not expect from the well-known scholar. Franko instructed him on how he could find old ethnographic documents and what kind of material would be interesting for NTSh. He was highly stimulated by this advice and handed in a chant from 1738. Hnatiuk also supported the young collector with hints on how he might conduct research in Transcarpathia. Zaklyns'ky was also very interested in the published calls for contributions, as he reacted to many of them, for example to the $E Z$ volume on bandits and historical tales. Even during World War I, when he served in the Sich Riflemen, he collected soldier songs on Hnatiuk's suggestion. ${ }^{130}$ After the war, when NTSh as well as other aspects of the region's intellectual life greatly transformed, he kept his connection to the ethnographic commission. ${ }^{131}$

Zaklyns'kyı̌ did not limit himself to folklore. He donated ethnographic and archaeological objects to the museum and many books and manuscripts to the library on several occasions since $1907 .{ }^{132}$ In 1913, he submitted a collection of drawings by his pupils, on another occasion - archaeological and ethnographical notes on Halych, as well as reported having found a coin during an excavation, which he had already sent to the museum. ${ }^{133}$ In 1918, he contributed a short paper on nutrition in Kosiv district to MURE. In that description he took up on Hnatiuk's and Franko's position against generalization of ethnographic regions, arguing that eating habits would even vary between two close villages. Most of his publications, including mostly popular-scientific

128 IMFE, f. 29-3, spr. 205, Rostyslav Zaklyns'ky’’s notebook, 1904; spr. 246-248, Materials by Ivan Saviak; IMFE, f. 28-3, spr. 178, ark. 27; Folk songs, collected by Zaklyns'kyı̆ R., Zaklyns'kyĭ B., IMFE, f. 29-3, spr. 78; IMFE, f. 29-3, spr. 79.

129 EZ XXXV, 1914, p. IV.

${ }^{130}$ IMFE, f. 29-3, spr. 245, War songs, collected by Bohdan Zaklyns'ky̌̆.

131 Kas'kiv 1998, pp. 78-83.

${ }_{132}$ Khronika 1907, Nr. 32, p. 2; 1908, Nr. 34, pp. 17; 1911, Nr. 45, p. 59.

133 IMFE, f. 28-5, spr. 566, Letter by Bohdan Zaklyns'kyı̆, 1913; IMFE, f. 28-5, spr. 177, Archaeological and ethnographical notes by Bohdan Zaklyns'ky̆̌, 1904. 
and pedagogical works, appeared independently from NTSh. ${ }^{134}$ While he was an expert for his region as well as for collecting, he did not have ambitions for a scientific career. This commitment was not one-sided. He was regularly rewarded with issues of NTSh periodicals and elected member of the ethnographic commission in October 1912. His father Roman and his brother Rostyslav were appointed ordinary members in 1914 , too. ${ }^{135}$

As opposed to this well remembered family, Ivan Voloshyns'kyı̌ (?-? $)^{136}$ is a barely known collector, who was situated in Daleshiv/ Daleszova, ${ }^{137}$ a village in the district Horodenka. His collection, which was submitted to the ethnographic commission, is now preserved in the Institute for Art Studies, Folklore and Ethnology of Ukrainian National Academy of Sciences (IMFE) and consists of 20 notebooks. ${ }^{138}$ Eight of them contain folk songs, five tales, four baiky (Ukrainian fables), two kolomyiky and other songs and one contains legends. His first record dates back to 1893 , when he exclusively collected folk songs. ${ }^{139}$ In 1897, he started to collect legends and since 1909, he focused on tales and baiky until 1913. ${ }^{140}$ Hnatiuk published two papers by Voloshyns'ky1 in MURE 1919. He followed Hnatiuk's wish and collected material on funeral customs and weddings between 1911 and 1913. ${ }^{141}$ This short history of collections clearly shows how the calls and questionnaires stimulated a dedicated researcher.

134 Kas'kiv 1998, pp. 80, pp. 172-179; cf. below for the position of Franko and Hnatiuk.

135 Khronika 1907, Nr. 32, p. 26; 1912, Nr. 52, p. 17; 1914, Nr. 57, p. 24.

136 Biographical data is also not secured. The online Encyclopedia of Modern Ukraine considers him a cleric and accounts for his death after 1917. However, there is no reliable evidence given for that. The cleric in Daleshiv/Daleszowa was Nykola Voloshyns'ky1, while no other person of this last name comes up in the respective directory of the Greek-Catholic diocese in Stanislaviv, to which the village was assigned. Cheremshyns'kyi 2006; Shematyzm vseho klyra breko-katolytskoy Eparkbiï Stanyslavivskoï na rik Bozbyi 1913, p. 33-34.

137 Today, the village is named Daleshove, Horodenkivs' kyi raion, Ivano-Frankivs'ka oblast'.

138 IMFE, f. 28-3, spr. 103-113; f. 29-3, spr. 206-214, Notebooks by Ivan Voloshyns'ky̌̆.

139 IMFE, f. 28-3, spr. 103-105.

${ }^{140}$ IMFE, f. 28-3, spr. 109-112; f. 29-3, spr. 206.

141 Materiialy do ukraïns'koï etnol'ogï 1919, 19-20, p. 194. 
His records are characterized by great attention to detail. Usually he placed all accents according to the local articulation, ${ }^{142}$ in opposite to Zaklyns'kyl. Voloshyns'kyı̌ also provided translations of dialectal terms, added references to similar folklore and most of his texts are well dated. ${ }^{143}$ Hence, they are a productive source, while only one collection of songs and kolomyzky, consisting of a cut up notebook and other loose paper, lacks detailed information. He also gave an overview of the motives of some baiky in case something would not be understandable since, as he emphasized, he would write down every story exactly as dictated. ${ }^{144}$

With only a few exceptions, ${ }^{145}$ all of Voloshyns'kyr's recordings originate from the village as well as neighboring places. His notebooks contained a few recordings prepared by his relatives, ${ }^{146}$ but the majority of them were written down by himself. Zaklyns'kyı̌ was a much more mobile researcher, as he recorded material in different regions in Galicia as well as in Volhynia and Transcarpathia. ${ }^{147}$ Many texts of them were cut out due to Hnatiuk's method of arranging the material for publication. The sole fact that 449 of his records were incorporated into the two volumes of EZ on demonology - that is roughly a third of the volume, published in 1912, ${ }^{148}$ documents the outstanding quantity and quality of his contributions.

Upon Hnatiuk's request, Voloshyns'kyĭ also collected ethnographic objects from his home village for the ethnographic museum of NTSh. For his support, he was able to receive literature as well as money. Hnatiuk also ordered relevant ethnographic books as a reward for Vo-

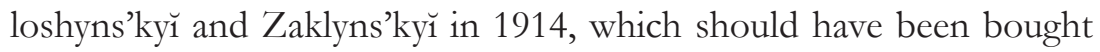
antiquarian if not available otherwise. ${ }^{149}$ Voloshyns'ky's bad health condition might have been responsible for the interruptions and the end of this extraordinary cooperation, ${ }^{150}$ but his biography is mostly unknown.

${ }^{142}$ E.g. in the notebooks IMFE, f. 29-3, spr. 206-209.

${ }_{143}$ IMFE, f. 29-3, spr. 213, ark. 6; Sokil 2009, p. 155.

144 IMFE, f. 29-3, spr. 207, ark. 1 zv.

145 IMFE, f. 28-3, spr. 213, ark. 2-7, Ethnographic material from Volhynia, collected by Bohdan Zaklyns'ky̆.

146 Sokil 2009, p. 155.

147 IMFE, f. 28-3, spr. 272; IMFE, f. 28-3, spr. 178.

148 EZ XXXIV, 1912, p. III.

149 Dashkevych (ed.) 1998, pp. 276-277.

${ }^{150}$ Hnatiuk 1916b, p. IX. 
Voloshyns'kyı̆ delivered extensive material from the ethnographic region of Pokuttya, situated in the south-eastern border region of Galicia. His work is highly relevant, as he managed to preserve fluent texts as well as objects from the region. ${ }^{151}$ The same conclusion is true for $\mathrm{Za}$ klyns'ky1, as he did the same for Kosiv (Pol. Kosów) district or respectively butsul'shchyna and Mykhailo Zubryts'kyl for boikivshchyna. The nexus between folklore - and other aspects of ethnography and anthropology - and region-building was shown foremost in terms of organization and cooperation. Kolomyrky are a suitable example to substantiate these observations with the content of research. They literally are an "invented tradition", ${ }^{152}$ extraordinary popular and a relevant feature of identity in Western Ukrainian lands, based on historical customs. Regionality is an important aspect of analysis in Ukrainian folkloristics, ethnography and their history, because research was usually influenced by these regional categories and relying on ethnic subgroups localized there. When it comes to the definition of regional identity, Franko and Hnatiuk never ceased to emphasize that overall generalization would be harmful, as it would conceal all the independent phenomena of subregions, villages or even parts of them. ${ }^{153}$ This position sums up why they spent all the energy on collecting and publishing material from small and otherwise rather unknown villages.

\section{A statistical survey and the Cisleithanian census}

Citizen science does not always have to be a highly successful longterm operation, as the following example shows. During January 1911, the statistical commission of NTSh surveyed localities in 40 Galician districts. The documents preserved in the Central Historical State Archive of Ukraine in Lviv consist of 290 questionnaires - processed by about 210 volunteers ${ }^{154}$ - and two letters by surveyors, while it remains unknown if these are all filled-in forms that were returned to NTSh. ${ }^{155}$

151 Sokil 2009.

152 Hobsbawm, Ranger 2013; for Folklore in this concept cf. p. 6.

${ }^{153}$ Kyrchiv 2002, pp. 8, 17.

154 Since not all volunteers filled in their name as required, the number is rounded.

155 Statistical data, TsDIAL, f. 309, op. 1, spr. 2547-2553. All of the documents in these folders, except the two letters, are the discussed statistical questionnaires, so that the subsequent references will not contain separate denominations. 
However, no concise evaluation of this data was ever conducted. In Hnatiuk's historical sketch on NTSh, prepared in 1924, the only definite confirmation on this matter is provided. He complained that the material has "remained hitherto unused", even though it contained "much valuable" 156 information. First of all, I want to scrutinize the possible reasons for the absent final evaluation of the questionnaires. Furthermore, these available documents allow a look at strategies, motivations and problems of citizen science on a broader scale. The material is also interesting as it is able to provide empirical evidence regarding theoretical positions on the influence of categories in the census. ${ }^{157}$ In order to do so, the process of organizing the commission and the execution of this project have to be reconstructed. Based on that, it is possible to discuss the volunteers, their efforts and problems with the accumulated data.

In 1906, NTSh founded a statistical commission to deal with Ukrainian national statistics, in Eastern Galicia as well as in other Ukrainian lands, to research the Habsburg census in particular and foster public awareness on the matter. The inspiration was sparked by Stanislav Dnistrians'ky of the Imperial Council (Reichsrat) in 1907. In the same year, he set statistics on the agenda of Ukrainian politicians by proposing - without success - to change the law on the census. This is barely a coincidence, considering the increasing importance of the decennial counting. In Galician-Ukrainian national discourse, the engagement with Habsburg language statistics was all but new. Two general issues were suitable to interest scientists, politicians and other national activists.

Firstly, the issue of equitable distributions of state resources between the respective national or language groups was addressed. The Cisleithanian census and its imprecise concept of Umgangsprache triggered mistrust in officials and served as explanation for believed denationalization. In Ukrainian-Ruthenian discourse, this was addressed shortly after the first time the category had come to use in the census of 1880 by a publicist Volodymyr Barvins'kyı (1850-1883). ${ }^{158}$ This

156 Hnatiuk 1984, p. 76.

157 Göderle 2016.

158 Barvins'ky1’s continued articles on the matter were reissued posthumously in Barvins'kyı 1901. For an overall discussion of the issues on Umgangssprache cf. Brix 1983; for Habsburg census in Galician-Ukrainian discourse Rohde 2016. 
perspective comes close to the idea of linkage between citizen rights and citizen science, ${ }^{159}$ as the corrected data and identified faults should have been used to demand equal distribution and support political arguments referring to this. Secondly, the ethnographic description of Ukrainian territories and their inhabitants was a topic most relevant for several projects of NTSh: on a regional level in order to discuss national predominance in the crown land Galicia or respectively its eastern part and on a transimperial level to describe the nation as a quantified whole. ${ }^{160}$ Both perspectives had the potential to be used in national propaganda, calling people to action by emphasizing danger and injustice. Already in August 1910, a campaign began to foster awareness for the assumed indications of the upcoming census, initiated by Dnistrians'kyl. This does not only concern a transregional newspaper campaign, but also agitation on the village level. ${ }^{161}$ Dnistrians'ky intended to use political as well as scholarly means to deal with statistical injustice - as he understood it. In Vienna, he directly addressed the Abgeordnetenhaus for many proven violations of the law by Galician officials in preparing and conducting the counting. Since his attempts would not bear fruit, he requested village priests to oversee the process and mediate if necessary. On a scientific level, he planned to conduct his own surveys to challenge the official results of the census.

While he openly communicated the plan of using mediators in the press as well as in the Abgeordnetenhaus, ${ }^{162}$ the intended surveys were kept secret for as long as possible. This fact already hints at the expected political problems, even though they were practically legal. Czech and German national organizations had already conducted similar initiatives regarding the census of 1900, afterwards broadly discussed in parliament. Regional authorities tried to prohibit projects like these, but their measures were not approved by the state, because such surveys did not categorically interfere with state affairs. ${ }^{163}$ Also, the published Chronicle of NTSh, which usually documented research projects in great detail, only mentioned that the historical-philosophical section had decided

159 Leach, Scoones 2005, p. 22.

160 Tomaschiwskyj 1908.

161 Dnistrians'ky 1910b.

162 Dnistrians'kyı̆ 1910 b.

163 Brix 1982, pp. 276-78. 
to ask the committee to pay for the production of questionnaires in November 1910. While the committee granted the requested money, as noted in the protocols, ${ }^{164}$ the published information remained silent about that matter, especially about the time when the surveys were to be conducted. It seems even unlikely that the publication was available before the surveys were conducted.

As the timing of the copies provided by NTSh indicate and a couple of hints in the letters and on the questionnaires prove, ${ }^{165}$ the survey was conducted in parallel to the official census executed in January 1911. The overwhelming mass of the surveyors were Greek-Catholic clergymen; in Drohobych/Drohobycz (4 persons), Kaminka Strumylova/Kamionka Strumiłowa (9), Zbarazh/Zbaraż (11), Zhydachiv/Żydaczów (6) and Zhovkva/Źółkiew (3), it was exclusively clerics doing the counting. ${ }^{166}$ Local knowledge of the clerics was exceptionally valuable for this kind of inquiry, since many of them served for long periods of time in the same village, took care of parish registers and worked with the local reading halls. Affiliates of Prosvita got to know how many people were actually taking part in cultural activities related to the Ukrainian language group. As sample checks from the Ternopil' area clarify, several of the people who counted were affiliated to, and often in a leading position of, a local Prosvita reading hall. ${ }^{167}$ Teachers, ${ }^{168}$ advocates ${ }^{169}$ and a student of the higher school of economics in Dubliany/Dublany ${ }^{170}$ volunteered as well. Advocates were an advancing stratum of secular

164 TsDIAL, f. 309, op. 1, spr. 34, ark. 130 zv., Protocols of the historical-philosophical section.

165 TsDIAL, f. 309, op. 1, spr. 2547, ark. 16-20, 52, 55; spr. 2550, ark. 22 zv., 39 zv.

166 TsDIAL, f. 309, op. 1, spr. 2548, ark. 23-26; spr. 2549, ark. 1-5, 5a, 6, 10-20; spr. 2550, ark. 1-9.

${ }^{167}$ Cf. the reports of local reading halls to the Ternopil'-branch: DATO, f. 294, op. 1, spr. 4, ark. 9-10, Spravozdanie $27^{\text {th }}$ October 1912; f. 294, op. 1, spr. 20, ark. 41 zv., Spravozdanie $26^{\text {th }}$ September 1911; f. 294, op. 1, spr. 29, ark. 3-4, Spravozdanie $12^{\text {th }}$ September 1909. Affiliated members match the persons in charge of counting in TsDIAL, f. 309, Op. 1, Spr. 2553, ark. 15, 17, 20. All in all, the reports to the regional Prosvita branches and the documents on the survey are neither consistent enough nor were they conducted in a matching timeframe to compare the involved personnel on a broader level.

168 TsDIAL, f. 309, op. 1, spr. 2551, ark. 34-35; spr. 2554, ark. 9.

169 TsDiAL, f. 309, op. 1, spr. 2547, ark. 29, 31; spr. 2554, ark. 15.

170 TsDiAL, f. 309, op. 1, spr. 2550, ark. 23. 
national elites that worked also in smaller towns. The lawyer Damian Savchak, who was responsible for two surveys in Borshchiv/Borszczów district, was a former deputy of the Galician sejm and a founding member of NTSh. ${ }^{171}$ The tasks Ukrainian volunteers would fulfill are therefore to be considered as "citizen science light" in Finke's conception. Anyway, there was no such thing as a 'professional' surveyor in the official census; these persons would be chosen and instructed by the respective village administration some time before the census. ${ }^{172}$

Dnistrians'kyi first articulated a detailed plan for the survey at the international Prosvita congress in 1909. He proposed a survey to investigate native languages, colloquial languages, language in family hierarchy, mixed-language and mixed-religion families, what part of the population was taking part in national literary or political life, what part affiliated itself with the nation or if migration or assimilation processes influenced the local conditions. ${ }^{173}$ One of the most pressing issues to be researched was the large number of latynnyky. This term was frequently used for persons of the Roman-Catholic rite speaking Ukrainian. Like other identities deviating from the 'usual' national combination of Ukrainian language and Greek-Catholic rite, the latynnyky constituted a challenge for the Ukrainian national movement. As NTSh historian Stepan Tomashivs'kyr stated on the very same congress, the latynnyky were constantly ignored by the national movement, creating a scenario in which the Ukrainian nation was most likely to "lose" them, if no action was taken. ${ }^{174}$ The congress decided that Prosvita should support the matter and handed it to the main council for execution. ${ }^{175}$

The first page of the questionnaire asked for the distributions of languages and rites in the village. Surveyors were supposed to answer them with the related number of inhabitants as well as their share of the total population. In the upper right corner, the data on rites from 1900 should be noted. Many answers contained only information

171 Khronika 1911, Nr. 45, p. 25.

172 Erinnerung betreffend Wabrung und Freiheit des Bekenntnisses der Umgangssprache bei der Volkszähblung 1910, AVA, k.k. Ministerium des Innern, Nr. 46485.

173 Dnistrians'kyı̌ 1910c, p. 197.

174 Tomashivs'ky 1910 , p. 106. The issue of latynnyky is described in detail in Pavlyshyn 2014; for their perception in NTSh cf. Rohde 2016.

175 Dnistrians'kyǐ 1910c, p. 201. 
e.g. on the share of Ruthenian speakers, having stated neither the quantity of the concerned inhabitants nor their total number, leaving the statistician without a hint on the actual quantitative relations. Some surveyors provided exact answers, just not noted in the unit the statisticians had in mind, for example when the question "which part of all inhabitants are speaking Polish at home?" was answered with "10 families". ${ }^{176}$ Someone else delivered only the official numbers of 1900 and submitted the questionnaire without any other addition. ${ }^{177}$ Other numbers were entered inconsiderately and hence just made no sense, such as the numbers delivered for Kuty (district Kosiv/Kosów), where about half of the 6,689 inhabitants were considered Jews, while 6,689 Jews were supposed to speak Polish. ${ }^{178}$ But the most frequent problem were estimates given instead of a real survey. ${ }^{179}$ That is very obvious when exclusively rounded figures were given. Often, only (vague) proportions were entered without giving any exact number for the state of the population in 1910.

The second page contained more complicated questions to be answered with a text. They primarily addressed the interrelation of rite and language of the village population. Hence they asked if there were mixed marriages between Roman and Greek-Catholics, what language they spoke; if there was a recent change of rites between these groups or historical change of rites of a larger group, respectively a Polish colony; were the village population in general or latynnyky in particular polonizing (polshchat' sia) or ruthenizing (rushchat' sia)? Were there latynnyky consciously describing themselves as Ruthenians? Were their clothing or customs any different? ${ }^{180}$ These questions were inspired by Dnistrians'kyı's earlier research agendas, but formulated in easier language and divided into less complicated subquestions. In five questions, additional terms were given in parentheses, so that they were understandable for everyone. For example, the question if there were Greek-Catholics "latinized" was thus translated to "change to Latin [rite, M.R.]"181.

176 TsDIAL, f. 309, op. 1, spr. 2550, ark. 1.

177 TsDIAL, f. 309, op. 1, spr. 2548, ark. 17, 19.

178 TsDIAL, f. 309, op. 1, spr. 2550, ark. 12.

179 TsDIAL, f. 309, op. 1, spr. 2550, ark. 2, 9, 70.

180 TsDIAL, f. 309, op. 1, spr. 2447, ark. 1 zv.

${ }^{181}$ Ibid. 
The only two questions containing abstract vocabulary without explanation were those asking about polonization or ruthenization. ${ }^{182}$ These questions were also those most frequently unanswered. Even these terms were easy to acquire, not only through a general feeling of language, but also through the newspapers of the last year: the populist daily Dïlo and the UNDP-weekly Svoboda were dispatched to almost every Prosvita reading hall. ${ }^{183} \mathrm{It}$ is therefore possible to interpret the indifference to these questions also as indifference to these nationalized categories. Take, for example, one person who filled out 17 of the 18 questionnaires for the district Pidhaitsi/Podhajce. The surveyor delivered statistical data for the region in great quantity, even though foremostly only the questions easiest to know, i.e. not the information on languages spoken at home; this is an indication for the data just being guessed or taken over from the official census. The second page he ignored in almost all of these forms, so that overall the documentation for this district was rather weak. ${ }^{184}$ This argumentation is not designed to stigmatize clerics or local volunteers in general, as some examples prove the opposite. Vasyl' Mydlovs'kyr, the local priest, described Rosokhach/ Rosochacz (district Kolomyia, Pol. Kołomyja) in exact numbers, answered all questions comprehensibly and provided additional information on problems of the organization of the official census. ${ }^{185}$ Since the number of clerics is overwhelming and not all volunteers can be categorized by their profession, a related investigation would not be promising. It might be more suitable to ask whether age/generation of the contributors allows any further conclusions, but this demands further research on lesser-known individuals.

Some persons surveyed two or more villages. They were often holding a position in the Greek-Catholic church that forced them to be mobile. This concerns either those being responsible for religious services in several places or clerics with specific tasks in the regional deanery. The most common examples are school inspectors taking care of a couple of villages, such as Liubomyr Zaryts'ky̆ in Berezhany/Brzeżany district

182 TsDIAL, f. 309, op. 1, spr. 2547, ark. 1 zv.

183 Cf. the reports in fn. 167.

184 TsDIAL, f. 309, op. 1, spr. 2551, ark. 13-20, 22-30.

185 TsDIAL, f. 309, op. 1, spr. 2550, ark. 10. 
or Ivan Koroliuk in Peremyshliany/Przemyślany district. ${ }^{186}$ A few persons, not affiliated with the church, conducted a striking quantity of surveys. Antin Rak was an official and well-known activist in the small town Vynnyky/Winniki. Not only was he an organizer of a choir and a theatre group, but he also served as secretary of the local Prosvita branch, where he initiated the building of a narodnyi dim in 1910. In the following year, he successfully promoted the Ukrainian National-Democratic Party on the local level. ${ }^{187} \mathrm{He}$ was responsible for counting ten communities in the surrounding area of Lemberg, ${ }^{188}$ similar to the case of Pidhaitsi/Podhajce. Stepan Baĭdala was an active member of the local Ukrainian-national community in Mostys'ka/Mościska. At least since 1907, he was an active member of the town's Prosvita branch and since 1910 he worked as head of their national credit cooperative. ${ }^{189}$ Several times, he did not answer questions in the intended way, but just wrote all over the second page that "it is a pure Polish colony" 190 . For Mostys'ka/Mościska, 28 questionnaires were submitted, 13 of them by Bẵala. Furthermore, there are 14 questionnaires from Mostys'ka/ Mościska without names of surveyors. The handwriting as well as the style of filling out the form is very similar to Baĭdala's. For this reason, one can assume that Baĭdala was responsible in a way for these as well. Compared to the size of the district, it was the numerically most intensely surveyed of the crown land due to Baĭdala's activism.

About these young political activists one can doubtlessly state that they conducted their work because they believed in the importance of the census for the sake of the nation, just as it was communicated by Dnistrians'ky̌r. It has to be doubted that one person was able to survey all the places alone. Other questionnaires indicated that they used help of like-minded colleagues (on one form six persons directly signed as responsible). ${ }^{191}$ Both of them were in influential positions in national

186 Shematyzm vseho klyra hreko-katolytskoy mytropolychoy arkhieparkhiy l'vôvskoy na rôk 1911. L'vôv 1910, pp. 217, 398; TsDIAL, f. 309, op. 1, spr. 2547, ark. 3-4; spr. 2551, ark. 11-12.

187 Vlock 1970, pp. 184-185; Levyts'kyı̆ 1970, pp. 210-211.

188 TsDIAL, f. 309, op. 1, spr. 2550, ark. 17-18, 20-21, 24, 27, 30, 41, 44, 46.

189 Martyn 2009, pp. 80-81.

190 TsDIAL, f. 309, op. 1, spr. 2550, ark. 4 zv.

191 TsDIAL, f. 309, op. 1, spr. 2547, ark. 28. 
organizations. It seems logical to consider that the tasks were delegated and the responsibility hence assumed in case of legal consequences. At least when it comes to the anonymous surveyors in Mostys'ka/Mościska district, this seems highly probable. The location of the regional center with a well-connected Prosvita branch supports this assumption.

To conclude, must this operation be regarded as a fail? Asserting that the collected data is entirely worthless would be an overstatement. As numerous examples regarding the first half of the questionnaires showed, the numeric data needed for statistical purposes was often incomplete, so that it could not be used for calculations. Whereas a detailed evaluation of the material was never conducted, it is safe to consider that the survey shaped the further perception of the crown land's statistics by political representatives and the statistical commission. This becomes evident in Volodymyr Okhrymovych's publication on Actual and Fictive Executions of Ruthenians in 1912, as his points arguing for horrific falsification of language data were certainly inspired by the incidents of the census including the collected information. Suitable examples of information valuable without correct and complete numbers are provided by the written answers; in the district of Rohatyn, four out of four people reported polonization, in Sambir it was six out of seven. ${ }^{192}$ These and other cases correspond with Okhrymovych's discussion of denationalization, latynnyky and fabricated "Poles of Greek rite". ${ }^{193}$ Furthermore, the incidents regarding the census helped foster public and political awareness for Ukrainian issues at the state level, as the degree of awareness fostered by activism resulted in many complaints directly to the Austrian Ministry of the Interior and indirectly voiced by Dnistrians'kyı̆ in parliament. The mistrust towards manipulated data and, consequentially, Polish officials, accompanied by these arguments, used to be important topoi in national propaganda during World War I and the Paris Peace Conference. ${ }^{194}$ It has to be assumed that all these consequences were directly intended, as they were thoroughly foreseeable by coordination the proposed research with the official conduction of the census. While the outcome was barely used as a contribution to science, it shaped the views of scientists.

192 TsDIAL, f. 309, op. 1, spr. 2551 ark. 41-44; spr. 2552, ark. 1-7.

193 Okhrymovych 1912, quotation p. 28.

194 Rohde 2016, pp. 100-107, 113-116. 
In comparison to direct, personal research for NTSh, there was no promise of integration, recognition or compensation. Quite the contrary, many clerics seemed to consider the task of overseeing the official counting as illegal and hence stayed away from participating. While Dnistrians'kyl assured them that it would not violate any existing law, ${ }^{195}$ there is no secure base for judging his influence on them. Rather, it can be assumed that the appeal of Metropolitan Sheptyts'kyı̆ was decisive for the large number of clerics participating. It was not only published in Svoboda, but also in the organs of the church. He warned against negative implications for the national movement as well as for the Greek-Catholic church. ${ }^{196}$ Therefore, he did not only emphasize the usual national argumentation of Dnistrians'kyı̌ and colleagues, but appealed to instances most relevant even for national-indifferent persons. It would be, however, erroneous to speak of encompassing success, considering that many districts had only very few volunteers.

Of course, not all affected districts were of particular interest, as they were ethnically more homogenous, such as Sniatyn/Śniatyn, Kosiv/Kosów and Tovmach/Towmacz. For others, such as Zhovkva/ Żółkiew, Bereziv/Brzozów and parts of Stry̌̃/Stryj, a huge number of falsifications were assumed by the statistical commission. ${ }^{197}$ As Tamara Scheer and Rok Stergar have recently argued, processes of public nationalization were not just a result "of the nationalist's pressure and the subsequent concessions of the Habsburg state", ${ }^{198}$ but catalyzed by bureaucratic classification practices, such as Umgangssprache in the census. The program was designed to counter undesired implications of the state's category, after initiatives with the same goal failed in parliament. ${ }^{199}$ However, the survey is a suitable example to discuss nationalization, national indifference and mistrust in state institutions simultaneously.

\footnotetext{
195 Dnistrians'ky 1910a.

196 N. N.1 1910.

197 Okhrymovych 1909, pp. 100-101.

198 Stergar, Scheer 2018, p. 586.

199 Rohde 2016, pp. 83-88.
} 


\section{Conclusion}

This paper covered examples of successful efforts on region-building from boikivshchyna, hutsul'shchyna, Pokuttya and Transcarpathia. Local experts and collectors provided material and support for research that is still relevant today for Ukrainian culture and regional identity, as they made the preservation of volatile oral literature possible to an extent, which would have been impossible to reach in this short timespan with NTSh's limited resources. The task to preserve and order the material was fulfilled by NTSh as long as it existed. After annexation of former Galicia by the Soviet Union, the material was assigned to different stateowned scientific organizations. ${ }^{200}$ Until today, the respective collections, among others, are valuable sources for scholarly work. ${ }^{201}$

Even though NTSh gave up a lot of its elitist habitus, this did obviously not lead to an overall democratization of science, as dreamt of by today's programs for citizen science. Considering the education level of Galician rural territories, this diagnosis is not surprising. The reforms opened up several opportunities to participate, for amateurs and adepts of science alike. When it came to the self-conception of NTSh's mission, this assessment has to be restricted: as the debate between Zubryts'kyı and Franko shows, popularizing science was not the agenda of NTSh's leadership. ${ }^{202}$ However, aspects of participation also served the scholarly education of interested locals. The duration of the collection programs contributed to the building of the scientific community. The statistical project, on the other hand, turned to existing networks Prosvita and the Greek-Catholic church - for support. Stimulation for their work was limited to questionnaires and information about sources of falsification by officials.

While commissioned work was regularly asked for, Hnatiuk exclusively addressed these local experts, who had already shown dedication for work of that kind, offering them stimulations by questionnaires and outlines of the proposed texts. Anyway, possible contributions were not

${ }^{200}$ For the fate of NTSh archives after annexation, cf. Svarnyk 2005.

201 Sokil 2011 is one of the latest examples.

202 I recently pointed at that issue in Rohde 2019, even though a more detailed and systematized treatment would be in order. However, that is only one field of disputes, as NTSh was frequently the stage of inner disagreements between Hrushevs'ky̌ and his allies versus other groups. Cf. Zaĭtseva 2006. 
limited to proposed topics. Properly individualized projects led to fruitful integration of locals, whereas the collection of statistical data suffered from communication. The complex and standardized categories of the questionnaires caused problems not regarding their language, but the related concepts. Nevertheless, the statistical inquiry contributed to national identification in the countryside as well as to the political recognition of Ukrainian demands by the state. This point illustrates how participation of locals could be "simultaneously functional and symbolic" 203 . In contrast to politically harmless collections, the census, its control and the additional survey by NTSh was part of the national conflict in Galicia. This had major implications, because different interest groups were mobilized or kept from participating. The surveyors did not have to be liubyteli and their work was nothing to do on a 'long winter evening' or during their holidays. They had to work under pressure of time and politics, which might be the major reason for the inconsistent quality of the results. The initial project was considered not only of situational value, but also for ethnographic description. From this standpoint, the influence of the project is marginal for Ukrainian history of science. However, it demonstrates the nexus of science and nationalization in the given period. But nationalization was no inevitable consequence of the participation in a scientific network, even in imperial context. As Coen has shown, the amateurs participating in earthquake observations were integrated on a supranational level. ${ }^{204}$ However, NTSh put considerable effort in the nationalization of its members and other participants. While the statistical observation included a certain politicization of the involved persons, it is not possible to transfer this aspect to the ethnographic work, where only mild (regional) patriotism can be assumed without additional sources.

Since prospective participants were narrowed down to specific groups ${ }^{205}$ determined by nationality (or at least language) and education,

${ }^{203}$ Vetter 2011, p. 136.

${ }^{204}$ Coen 2013, pp. 141-162.

205 The given cases do not allow any generalization in terms of generation or geographical background, as the discussed contributors were fairly heterogenous. Such a conclusion could only be drawn from a close network analysis of a much larger amount of contributors. Unfortunately, the lost documents from NTSh administration during World War I would complicate such an undertaking. 
the universal approach of the term 'citizen science' seems partly inappropriate for the given case study. While terms like 'lay' or 'amateur' participation bear the linguistic burden of suggesting a certain lack of expertise, the opposite proves to be true when it comes to the factor of local knowledge in given regions: Locality and local expertise were crucial, as the vast countryside of Eastern Galicia posed an impediment for the projects. Therefore, participants from the village intelihentsia might as well be considered 'local experts'. As the story of Hnatiuk shows, engagement in tasks like collecting folklore or describing local customs was an opportunity to establish contact with the scientific community. Cooperation usually started as a top-down relation, limiting the contributions to the mentioned tasks. In some cases of long-lasting affiliation, local experts had the possibility to renegotiate their status and become members of NTSh, providing them with greater possibilities to transcend borders between the discussed classifications. This was bound to individual expertise and willingness to devote time. In contrast to this phenomenon, many contributors remained 'amateurs' (positively understood as 'enthusiasts'), limiting their engagement to pursuing ethnographic research as leisure time activity. For local experts, aspects such as getting recognized by being allowed to contribute, being rewarded with a book or a small, yet symbolical amount of money or finally, such as Zubryts'kyl, being elected a 'real member' of NTSh, seem to be more relevant than demands of alternative scientific discourses. NTSh, ingratiating itself with the locals by paying them and local matters attention, was also considered the institutional alternative to more elitist or non-vernacular approaches to science.

\section{Acknowledgments}

Thanks are due to the German-Ukrainian Historians' Commission and the International Relations Office, University of Innsbruck, for providing me with the possibility for several research stays in L'viv and Kyiv. I also want to express my gratitude to Stefan Hechl, Kurt Scharr, Phillip Schroeder, Jan Surman and the two anonymous reviewers for their helpful comments and language corrections on earlier drafts of this paper. 


\title{
Bibliography
}

\author{
ARCHIVES \\ Central State Historical Archives of Ukraine L'viv (= TsDIAL), Fond 309: \\ Naukove tovarystvo im. Shevchenka. \\ Institute for Art Studies, Folklore and Ethnology of Ukrainian National Academy \\ of Sciences Kyïv. (= IMFE), Fond 28: Volodymyr Hnatiuk, Fond 29: Etno- \\ hrafichna komisiia NTSh. \\ Allgemeines Verwaltungsarchiv, Vienna: Ministerium des Innern. \\ Archiv Museum für Volkskunde, Vienna. \\ Institute of Manuscripts, National Library of Ukraine, Fond 170: Boris Hrinchenko.
}

\section{PERIODICALS}

Etnohrafichnyi zbirnyk. L'viv. (= EZ)

Khronika ukrä̈n'ko-rus'koho Naukovoho tovarystva imeny Shevchenka. L'viv. (= Khronika)

Literaturno-Naukovyi V istnyk. L’viv 1904.

Materiialy do ukraïns'ko-rus'koï etnol'ogiï (from T. 11, 1909 = Materiïaly do ukraïns'koï etnol'ogii). L'viv.

\section{LITERATURE AND PUBLISHED SOURCES}

Acham, Karl (ed.) 2002: Geschichte der österreichischen Humanwissenschaften: Bd. 4: Geschichte und fremde Kulturen. Wien: Passagen Verlag.

Bartov, Omer; Weitz, Eric D. (eds.) 2013: Shatterzone of Empires: Coexistence and Violence in the German, Habsburg, Russian, and Ottoman Borderlands. Bloomington: Indiana University Press.

Barvins'ky1̆, Oleksandr 1892: Pro zasnovannie i doteperishniĩ rozvytok tovarystva im. Shevchenka u L'vovi. [In:] Zapysky Naukovoho tovarystva imeny Shevchenka 1, pp. 209-212.

Barvins'kyı̆, Volodymyr 1901: Doslidy z polja statystyky. ("Literaturno-naukova biblioteka", vol. 17). L'viv: Naukove tovarystvo im. Shevchenka.

Baycroft, Timothy; Hopkin, David M. (eds.) 2012: Folklore and Nationalism in Europe During the Long Nineteenth Century ("National Cultivation of Culture", vol. 4). Leiden, etc.: Brill.

Brix, Emil 1982: Die Umgangssprachen in Altösterreich zwischen Agitation und Assimilation. Die Sprachenstatistik in den zisleithanischen Volkszäblungen, 1880 bis 1910. Wien, etc.: Böhlau. 
Coen, Deborah R. 2013: The Earthquake Observers: Disaster Science from Lisbon to Richter. Chicago, etc.: The University of Chicago Press.

Dabrowski, Patrice M. 2005: "Discovering" the Galician Borderlands: The Case of the Eastern Carpathians. Slavic Review 64(2), pp. 380-402.

Dabrowski, Patrice M. 2008: Constructing a Polish Landscape: The Example of the Carpathian Frontier. Austrian History Yearbook 39, pp. 45-65. DOI: https:// doi.org/10.1017/S0667237808000047 (purchase PDF).

Dabrowski, Patrice M. 2013: Borderland Encounters in the Carpathian Mountains and Their Impact on Identity Formation. [In:] Bartov, Omer; Weitz, Eric D. (eds.): Shatterzone of Empires: Coexistence and Violence in the German, Habsburg, Russian, and Ottoman Borderlands. Bloomington: Indiana University Press, pp. 193-208.

Dashkevych, Ia. (ed.) 1998: Volodymyr Hnatiuk: dokumenty i materiialy (1871-1989). L'viv: Naukove tovarystvo im. Shevchenka u L'vovi.

Dnistrians'ky̆́, Stanyslav 1910a: V spravi konskryptsyii. Svoboda XIV, 15 ${ }^{\text {th }}$ December 1910 , Nr. 50 , p. 8.

Dnistrians'ky̌́, Stanyslav 1910b: Shcho treba kozhdomu znaty pro spys naselenia. Svoboda XIV, Nr. 32 (11 $1^{\text {th }}$ August 1910), pp. 2-3; Nr. 33 (18 $8^{\text {th }}$ August 1910), pp. 4-5.

Dnistrians'ky̌̆, Stanislav 1910c: Narodna statystyka. [In:] Kotsiuba, Mykhaĭlo;

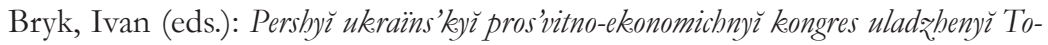
varystvom „Pros'vita” u L'vovi v dniakh 1. i 2. liutoho 1909. roku. Protokoly i referaty. L’viv: Pros'vita, pp. 193-201.

Dovhaliuk, Iryna 2016: Fonohrafuvannia narodnoï muzyky v Ukraïni: istoriia, metodolobiia, tendentsiï. L'viv: LNU.

Dragomanov, M.; Antonovich, V. 1874-1875: Istoricheskiia pesni malorusskago naroda sobiasneniiami Vl. Antonovicha i M. Dragomanova. Kiev.

Finke, Peter 2014: Citizen Science. Das unterschätz̨te Wisse der Laien. München.

Franko, Ivan 1905a: Deshcho pro nashu presu. Lïteraturno-Naukovy̌̆ Vistnyk' T. 31, kn. 7, pp. 62-71, 76-81.

Franko, Ivan 1905b: Eine ethnologische Expedition in das Bojkenland. Zeitschrift für österreichische Volkskunde XI, pp. 17-32, 98-115.

Franko, Ivan 1906: Bel parlar gentile. Literaturno-Naukoyyz̆ Vistnyk T. 33, kn. 2, pp. 284-296.

Franko, Oksana O. 2000: Fedir Vovk. Vchenyı̆ i hromadsky̆ diiach. Kyïv: Vydavnytstvo Ievropers'koho universytetu. 
Gammerl, Benno 2010: Staatsbürger, Untertanen und Andere. Der Umgang mit ethnischer Heterogenität im Britischen Weltreich und im Habsburgerreich 1867-1918. Göttingen: Vandenhoeck \& Ruprecht.

Göderle, Wolfgang 2016: Zensus und Ethnizität. Zur Herstellung von Wissen über soziale Wirklichkeiten im Habsburgerreich zwischen 1848 und 1910. Göttingen: Wallstein.

Grieshofer, Franz 1998: Die Bedeutung des Ausstellungswesens für die Entwicklung der Ethnographie in Galizien und Wien. [In:] Plöckinger, Veronika; Göttke-Krogmann, Ulrich; Beitl, Matthias; Beitl, Klaus (eds.): Galizien. Ethnographische Erkundung bei den Bojken und Huzulen in den Karpaten: Begleitbuch zur Ausstellung '98 im Ethnographischen Museum Schloss Kittsee vom 6. Juni bis 2. November 1998. Wien: Selbstverl. des Österr. Museums für Volkskunde, pp. 19-42.

Himka, John-Paul 1988: Galician Villagers and the Ukrainian National Movement in the Nineteenth Century. Houndmills, etc.: McMillan.

Himka, John Paul 1999: Religion and Nationality in Western Ukraine. The Greek Catholic Church and the Ruthenian National Movement in Galicia, 1867-1900. Montreal \& Kingston, etc.: McGill-Queen's University Press.

Hirschhausen, Ulrike von 2012: People that count. The Imperial Census in Europe and India in Nineteenth and Early Twentieth-Century Europe and India. [In:] Leonhard, Jörn; Hirschhausen, Ulrike von (eds.): Comparing Empires. Encounters and Transfers in the Long Nineteenth Century. Göttingen: Vandenhoeck \& Ruprecht, pp. 145-170.

Hnatiuk, Volodymyr 1916a: Ukraïns'ka narodna sloves'nist': V spravi zapysiv ukrä̈n'koho etnografichnoho materialu. Viden': Soiuz vyzvolennia Ukraïny.

Hnatiuk, Volodymyr 1916b: Peredne slovo. Etnohrafichnyı̆ abirnyk XXXVII-XXXVIII, pp. III-XII.

Hnatiuk, Volodymyr 1898: Vidozva do vsikh liubyteliv nashoï narodnoï slovesnosty. Bukoyyna 73, p. 3.

Hnatiuk, Volodymyr 1984: Naukove Tovarystvo imeny Shevchenka u L'vovi. Istorychny̆ narys pershoho 50-richchia - 1873-1923 ("Serie: Monographien”, vol. 36). München: Ukrainische Freie Universität.

Hobsbawm, Eric J.; Ranger, Terence O. 2013: Introduction: Inventing Traditions. [In:] Hobsbawm, Eric J., Ranger, Terence O. (eds.): The Invention of Tradition. Cambridge, UK etc.: Cambridge University Press, pp. 1-14.

Hobsbawm, Eric J.; Ranger, Terence O. (eds.) 2013: The Invention of Tradition. Cambridge, UK etc.: Cambridge University Press.

Hrytsak, Iaroslav 2006: Prorok u svoï viť́y zni: Franko ta joho spil'nota (1856-1886). Kyïv: Vydavnytstvo Chasopys "Krytyka". 
Hrytsak, Yaroslav 2008-2009: How Sissi Became a Ruthenian Queen: On Some Peculiarities of the Peasant Worldview. Journal of Ukrainian Studies 33-34, pp. 227-237.

Ivaniuta, Ihor P. 2002: Naukova ta hromads'ko-politychna diial'nist' akademika Volodymyra Hnatiuka v konteksti ukraïn'koho natsional'noho vidrodzhennia kintsia XIX pochatku XX st. Dysertatsiia TDPU, Ternopil'.

Judson, Pieter M. 2006: Guardians of the Nation. Activists on the Language Frontiers of Imperial Austria. Cambridge, MA, etc.: HUP.

Kaindl, Raimund Friedrich 1903: Die Volkskunde. Ihre Bedeutung, ihre Ziele und ihre Methoden. Leipzig, etc.: Deuticke.

Karpenko, Andriı 2016: Volodymyr Shukhevych - spivorhanizator kraievoï vystavy u L'vovi 1894 roku. Narodoznavchi zoshyty 130(4), pp. 785-791.

Kas'kiv, Oleksandra I. 1998: Prosvitnyts'ka diial'nist' i pedahohichni pohliady B. Zak.lyns'koho. Dysertatsiia PNU, Ivano-Frankivs'k.

Kolessa, Filiaret 2005: Istorïa ukraïns'koï etnohrafï. Kyïv: IMFE 2005.

Kolessa, Filiaret 1907: Rytmika ukraïn'kykh narodnykh pisen'. L'viv: Naukove tovarystvo im. Shevchenka.

Kotsiuba, Mykhailo; Bryk, Ivan (ed.) 1910: Pershy̆ ukrä̈n'ky̌ pros'vitno-ekonomichny̌̆ kongres uladz̧heny̌ Tovarystvom "Pros'vita" u L'vovi v dniakh 1. i 2. liutoho 1909. roku. Protokoly i referaty. L'viv: Pros'vita.

Kratochvil, Alexander; Makarska, Renata; Schwitin, Katharina; Werberger, Annette (eds.) 2013: Kulturgrenzen in postimperialen Räumen: Bosnien und Westukraine als transkulturelle Regionen. Bielefeld: transcript.

Kupchyns'kyı̆, Oleh (ed.) 2001: 125 rokiv Naukovoho tovarystva imeni Shevchenka. Zbirnyk naukovych prats' i materialiv, prysyyachenyz imvileiu Tovarystva. L'viv: Naukove tovarystvo im. Shevchenka.

Kupchyns'ky̆̌, Oleh (ed.) 2013: Naukove tovarystvo im. Shevchenka. Doslidæhennia, materialy ("Ukraïnoznavcha naukova biblioteka NTSh", vol. 37). L'viv: Naukove tovarystvo im. Shevchenka.

Kupchyns'kyr̆, Oleh 2013: Statuty, proekty statutiv i reglamenty (reguliaminy) Tovarystva im. Shevchenka ta Naukovoho tovarystva im. Shevchenka. 1873-1989. [In:] Kupchynsky̆, Oleh (ed.): Naukove tovarystvo im. Shevchenka. Doslidz̧hennia, materialy ("Ukraïnoznavcha naukova biblioteka NTSh", vol. 37). L'viv: Naukove tovarystvo im. Shevchenka, pp. 19-139.

Kuzelia, Zenon 1908: Bợkivs'ke vesilie v Lavochnim (stryı̌s'koho povita). Materiialy do ukraïns'ko-rus'koï etnol'ogï $\mathrm{X}$, pp. 121-150. 
Kuziela, Z. [Kuzelia, Zenon] 1930: Die ukrainische Volkskunde. [In:] Zalozieckyj, V. (ed.): Das geistige Leben der Ukraine in Vergangenheit und Gegenwart ("Deutschtum und Ausland", vol. 28/29). Münster: Aschendorffsche Verlagsbuchhandlung, pp. 164-182.

Kyrchiv, Roman (ed.) 2002: Iz fol'klornykh rehioniv Ukraïny: Narysy ü statti. L'viv: Instytut narodoznavstva NAN Ukraïn.

Kyrchiv, Roman 2008: Zviasky Mykhaụla Zubryts'koho z Ivanom Frankom i Volodymyrom Hnatiukom. Narodoznavchi zoshyty (3-4), pp. 373-377.

Kyrchiv, Roman 2002: Rehional'nist' fol'klornoï tradytsiï. [In:] Kyrchiv, Roman (ed.): Iz fol'klornykh rehioniv Ukrä̈y: Narysy ü statti. L'viv: Instytut narodoznavstva NAN Ukraïny, pp. 7-32.

Leach, Melissa; Scoons, Ian; Wynne, Brian (ed.) 2005: Science and Citizens. Globalization and the Challenge of Engagement ("Claiming citizenship: rights, participation, and accountability”, vol. 2). London - New York.

Leach, Melissa; Scoons, Ian 2005: Science and Citizenship in a Global Context. [In:] Leach, Melissa; Scoons, Ian; Wynne, Brian (ed.): Science and Citizens. Globalization and the Challenge of Engagement ("Claiming Citizenship: Rights, Participation, and Accountability”, vol. 2). London - New York, pp. 15-38.

Leonhard, Jörn; Hirschhausen, Ulrike von (eds.) 2012: Comparing Empires. Encounters and Transfers in the Long Nineteenth Century. Göttingen: Vandenhoeck \& Ruprecht.

Levytsky̆̌, Jaroslav 1970: Vid natsional'noho vidrodzhennia do vytvol'noyi borot'by. [In:] Vlokh, Mykhailo (ed.): Vynnyky - Zvenyborod - Univ ta dovkil'ni sela. Istorychno-memuarnyj zbirnyk. Chicago 1970, pp. 206-220.

Linkiewicz, Olga 2016: Scientific Ideals and Political Engagement: Polish Ethnology and the 'Ethnic Question' Between the Wars. Acta Poloniae Historica 114, pp. 5-27. DOI: http://dx.doi.org/10.12775/APH.2016.114.01.

Lozyns'kyı̆, Mykhaŭlo 1908: Sorok lit diial'nosty "Pros'vity”. L'viv: Vydavnytstvo Tovarystva "Pros'vita".

Makarska, Renata 2010: Der Raum und seine Texte: Konzeptualisierungen der Hucul'šyna in der mitteleuropäischen Literatur des 20. Jahrhunderts ("Europäische Hochschulschriften. Reihe XVI, Slawische Sprachen und Literaturen”, vol. 78), Frankfurt am Main - New York.

Martyn, Bohdan 2009: Mostys'ka i Mostyshchyna vid nắdavnishykh chasiv do XXI-ho st. Mostys'ka: author's edition.

Mazurok, Oleh 2010: “... Naibil'sh uchenyǐ i naíbil'sh kompetentnyz v etnohrafichnykh spravakh sviashchenyk-rusyn u tsiliu Uhorshchyni”: Do 155-richchia vid dnia narodzhennia Iuriia Zhatkovycha. Uzhhorod: Vydavnytstvo "Karpats'ka Vezha". 
McCray, W. Patrick 2006: Amateur Scientists, the International Geophysical Year, and the Ambitions of Fred Whipple. Isis 97(4), pp. 634-658. Available online: https://www.jstor.org/stable/10.1086/509947.

Mueller, Michael; Tippins, Deborah; Bryan, Lynn 2012: The Future of Citizen Science. Democracy and Education 20(1), pp. 1-12. Available online (20.06.2018): https://democracyeducationjournal.org/home/vol20/iss1/2.

Mushynka, Mykola 2001: Ivan Pan'kevych i Naukove tovarystvo imeni Shevchenka. [In:] Kupchyns'kyı̆, Oleh (ed.): 125 rokiv Nankovoho tovarystva imeni Shevchenka. Zbirnyk naukovych prats' i materialiv, prysvyacheny i iuvileiu Tovarystva. L'viv: Naukove tovarystvo im. Shevchenka, pp. 79-90.

Mushynka, Mykola 2012: Volodymyr Hnatiuk. Zhyttia ta ioho diial'nist'v haluzi fol'klorystyky, literaturoznavsta ta movoznavstva. Ternopil': Bohdan.

Mushynka, Mykola 2008: Vzaiemyny Ivana Franka z Volodymyrom Hnatiukom. [In:] Vakarchuk, Ivan (ed.): Ivan Franko. Dukh, nauka, dumka, volia: materialy miz̧hnarodnoho naukohovo kongresu, prysviachenoho 150-richchiu vid dnia narodz̧hennia Ivana Franka (L'viv, 27 veres. - 1 z̧hovt. 2006 r.). L’viv: LNU, pp. 945-953.

Mushynka, Mykola (ed.) 1992: Vid Naukovoho tovarystva im. Shevchenka do Ukrä̈n'koho Vil'noho Universytetu. Mizhnarodna naukova konferentsiia. Kyï, etc.: Instytut ukraïns'koï arkheohrafiï.

Mushynka, Mykola 1987: Volodymyr Hnatiuk. Bibliohrafiia drukovanykh prats'. Edmonton: Kanads'ky.

Myshanych, Oleksa 1992: Rol' V. Hnatiuka v literaturnomu protsesi Zakarpattia kintsia XIX - pershoï chverti XX st. [In:] Mushynka, Mykola (ed.) 1992: Vid Naukovoho tovarystva im. Shevchenka do ukraïns'koho Vil'noho Universytetu. Miz̧hnarodna naukova konferentsiïa. Kyï, etc.: Instytut ukraïns'koï arkheohrafii, pp. 29-39.

N. N.1 1910: Konskryptsyia. Svoboda XIV, Nr. 52(29th December 1910), pp. 2-3.

N. N.2 1973: Slovnyk ukrajinskö̈ movy. Vol. 4. Kyï: Naukova dumka.

N. N.3 2001: Lystuvannia Mykhaila Hrushevs'koho ta Fedora Vovka 2001. [In:] Vynar, Lyubomyr (ed.): Lystuvannia Mykhaila Hrushevs'koho, T. 2. Kyiv et al. 2001, pp. 93-221.

Nakhlik, Ievhen (ed.) 2016: Frankivs'ka entsyklopediia, T. 1. L’viv: Vydavnytstvo "Svit".

Nakhlik, Ievhen; Sheremeta, Oksana 2016: Hnatiuk Volodymyr Mykhaĭlovych. [In:] Nakhlik, Ievhen (ed.): Frankivs'ka entsyklopediia, T. 1. L'viv: Vydavnytstvo "Svit", pp. 360-387. 
Naulko, V.; Rudenko, N.; Franko, O. (eds.) 2001: Lystuvannia Fedora Vovka z Volodymyrom Hnatiukom. L'viv 2001, etc.: Instytut ukraïns'koï arkheohrafii ta dzhereloznavstva im. M. S. Hrushevs'koho.

Okhrymovych, Volodymyr 1912: Faktychni i fiktyuni straty rusyniv v demografichnim biliantsi Halychyny za desiatlylitie 1900-1910. Statystychna rozvidka. L'viv: Vydavnychna Spilka.

Okhrymovych, Volodymyr 1909: Z polia nacional'noï statystyky Halychyny. Studï zpolja suspil'nykh nauk $i$ statystyky 1 , pp. 65-160.

Pan'kevych, Ivan 1926: Ivan Franko i Zakarpattie. Lïteraturno-Naukovyĭ Vistnyk 90, pp. 292-294.

Patsaŭ, Tamara A. 2013: Zenon Kuzelia. Zhyttia i narodoznavcha diial'nist'. L'viv.

Pavlyshyn, Oleh 2014: Dylema identychnosty, abo istoriia pro te, jak "latynnyky" (ne) staly ukraïncamy/poliakamy (Halychyna, ceredyna XIX - persha polovyna XX st.). Ukraïna moderna 21, pp. 179-218.

Petrenko, Olena 2016: Die ukrainische historische Zunft und die nationale Geschichte. Jahrbücher für Geschichte Osteuropas. Nene Folge 64(4), pp. 636-640.

Plöckinger, Veronika; Göttke-Krogmann, Ulrich; Beitl, Matthias; Beitl, Klaus (eds.) 1998: Galizien. Ethnographische Erkundung bei den Bojken und Huqulen in den Karpaten: Begleitbuch zur Ausstellung'98 im Ethnographischen Museum Schloss Kittsee vom 6. Juni bis 2. November 1998. Wien: Selbstverl. des Österr. Museums für Volkskunde.

Plokhy, Serhii 2005: Unmaking Imperial Russia. Mykhailo Hrushevsky and the Writing of Ukrainian History. Toronto.

Renn, Jürgen (ed.) 2012: The Globalization of Knowledge in History ("Max Planck Research Library for the History and Development of Knowledge. Studies" 1). Berlin: Max-Planck-Institut 2012, pp. 369-397. Available online (20.06.2018): http://edition-open-access.de/media/studies/1/Studies1.pdf.

Renn, Jürgen 2012: Survey: The Place of Local Knowledge in the Global Community. [n:] Renn, Jürgen (ed.): The Globalization of Knowledge in History ("Max Planck Research Library for the History and Development of Knowledge. Studies" 1). Berlin: Max-Planck-Institut, pp. 323-348. Available online (20.06.2018): http://edition-open-access.de/media/studies/1/Studies1.pdf.

Rohde, Martin 2016: Statistik im imperialen Kontext. Der Zensus der Habsburgermonarchie, Ostgalizien und die statistische Kommission der Naukove Tovarystvo im. Ševčenka. M.A. thesis, Göttingen.

Rohde, Martin 2019: Innerimperiale Lernprozesse? Die Nationalitätenproblematik der Innsbrucker Universität im frühen 20. Jahrhundert aus galizisch-ukrainischer Perspektive. [In:] Scharr, Kurt; Barth-Scalmani, Gunda (eds.): 
Die Gegenwart des Vergangenen im urbanen Raum Czernowitz-Innsbruck. Projektergebnisse eines gemeinsamen Studierendenprogrammes der Universitäten Czernowitz und Innsbruck über das kulturelle Erbe im öffentlichen Raum. Innsbruck: IUP, pp. 183-204.

Romanenchuk, Bohdan 1981: Doslidnyk "nerushenoho terenu"; peredmova. Zapysky Naukovoho tovarystva im. Shevchenka 201, pp. 5-23.

Sapeliak, Oksana A. 2000: Etnohrafichni studï v Naukovomu tovarystvi im. Shevchenka (1898-1939 r.r.). L'viv: Instytut narodoznavstva NAN Ukraïny.

Scharr, Kurt; Barth-Scalmani 2011: “Mit vereinten Kräften!'”: Raumkonstruktion und politische Kommunikation im Kronprinzenwerk. Österreich in Geschichte und Literatur (mit Geographie) 55(2), pp. 92-108.

Scharr, Kurt; Barth-Scalmani, Gunda (eds.) 2019: Die Gegenwart des Vergangenen im urbanen Raum Czernowitz-Innsbruck. Projektergebnisse eines gemeinsamen Studierendenprogrammes der Universitäten Czernowitz und Innsbruck über das kulturelle Erbe im öffentlichen Raum. Innsbruck: IUP.

Schwitin, Katharina 2013: Ruthenische Folklore im Fokus der polnischen Folkloristik und Ethnographie in der ersten Hälfte des 19. Jahrhunderts. [In:] Kratochvil, Alexander etc. (eds.): Kulturgrenzen in postimperialen Räumen: Bosnien und Westukraine als transkulturelle Regionen. Bielefeld: transcript, pp. 61-97.

Shematyzm vseho klyra hreko-katolytskoy Eparkhï Stanyslavivskoü na rik Bozhyž 1913. Stanyslaviv 1913.

Shematyzm vseho klyra hreko-katolytskoy mytropolychoy arkhieparkhiy l'vôvskoy na rôk 1911. L’vôv 1910.

Sheremeta, Oksana M. 2003: Volodymyr Hnatiuk i ukerä̈n'ka etnohrafichna nauka kintsia XIX - pochatku XX stolittia. Dysertatsiia: Instytut ukraïnoznavstva im. I. Kryp’iakevycha, L'viv.

Shuttleworth, Sally 2017: Life in the Zooniverse: Working with Citizen Science. Journal of Literature and Science 10(1), pp. 46-51. DOI: 10.12929/jls.10.1.09. Available online (20.06.2018): https://conscicom.files.wordpress.com/2017/06/ sally-shuttleworth-life-in-the-zooniverse-for-journal-of-literature-and-science-2017.pdf.

Sokil, Hanna 2009: Halyts'ki fol'klorysty ta ïkhni zapysy usnoï slovesnosti. Narodoznavchi zoshyty 1-2, pp. 147-158.

Sokil, Hanna 2011: Ukeräns'ka fol'klorystyke v Halychyni. Kintsia XIX - pershoü tretyny XX stolittia: istoryka-teoretychnyž dyskurs. L’viv: LNU.

Stachel, Peter, Die Harmonisierung national-politischer Gegensätze und die Anfänge der Ethnographie in Österreich. [In:] Acham, Karl (ed.) 2002: Geschichte der österreichischen Humanwissenschaften: Bd. 4: Geschichte und fremde Kulturen. Wien: Passagen Verlag, pp. 323-368. 
Stauter-Halsted, Keely 2001: The Nation in the Village: The Genesis of Peasant National Identity in Austrian Poland, 1848-1914. Ithaca, NY etc.: Cornell University Press.

Stergar, Rok; Scheer, Tamara 2018: Ethnic Boxes: the Unintended Consequences of Habsburg Bureaucratic Classification. Nationalities Papers 46(4), pp. 575-591. DOI: https://doi.org/10.1080/00905992.2018.1448374.

Struve, Kai 2005: Bauern und Nation in Galiz̨ien. Über Zugehörigkeit und soziale Emanzipation im 19. Jahrbundert. Göttingen: V\&R.

Surman, Jan [Forthcoming]: Science and Terminology in-between Empires: Ukrainian Science in a Search for Its Language in the 19th Century. Author's manuscript, to be published in Kritika.

Svarnyk, Halyna 2005: Arkhivni ta rukopysni abirky Naukovoho tovarystva im. Shevchenka $v$ Natsional'niu bibliotetsi u Varshavi: kataloh-informator. Warsaw, etc.: Vydavnytstvo "Ukraïns'kyı̆ arkhiv".

Sysyn, Frank 2012: Religion within the Ukrainian Populist Credo: The Enlightened Pastor Mykhailo Zubrytsky. Journal of Ukrainian Studies 37, pp. 85-96.

Sysyn, Frank 2013: Otets' Mykhaĭlo Zubryts'kyl̆. Nestor ukraïns'koho sela. [In:] Zubryts'ky1̆, Mykha1̌lo (ed.): Zibrani tvory i materialy u tr'okh tomakh, T. 1: Naukovy pratsi. L'viv, pp. 15-41.

Tarnavs'kyl̆, Roman 2013: Stanislav Tsishevs'ky1̆. Zhyttiepys, naukovi pratsi ta pedahohichna diialnist'. Narodoznavchi zoshyty 110(2), pp. 279-288.

Tomaschwskyj, Stefan 1908: Zur Karte des ukrainischen Wohngebietes. Ukrainische Rundschau VI(2), pp. 9-14.

Tomashiws'kyl̆, Stepan 1903: Uhors'ki Rusyny v s’vitlï madiars'koï uriadovoï statystyky. Zapysky Naukovoho tovarystva im. Shevchenka XII(VI), pp. 1-46.

Tomashiws'kyl̆, Stepan 1910: Pros'vitni vydavnytstva. [In:] Kotsiuba, Mykhaĭlo; Bryk, Ivan (ed.): Pershy̌ ukrä̈n'kyž pros'vitno-ekonomichny̌ kongres uladz̧henyı̆ Tovarystvom "Pros'vita" u L'vovi v dniakh 1. i 2. liutoho 1909. roku. Protokoly i referaty. L'viv: Pros'vita, pp. 96-110.

Vakarchuk, Ivan (ed.) 2008: Ivan Franko. Dukh, nauka, dumka, volia: materialy mizhnarodnoho naukohovo kongresu, prysviachenoho 150-richchiu vid dnia narodz̧hennia Ivana Franka (L'viv, 27 veres. - 1 zhovt. 2006 r.). L'viv: LNU.

Vetter, Jeremy 2011: Introduction: Lay Participation in the History of Scientific Observation. Science in Context 24(2), pp. 127-141. DOI: https://doi. org/10.1017/S0269889711000032.

Vlokh, Mykhaǔlo 1970: Antin Rak. [In:] Vlokh, Mykhaŭlo (ed.): Vynnyky - Zvenyborod - Univ ta dovkil'ni sela. Istorychno-memuarny̌̆ zbirnyk. Chicago: Ukrainian Museum of Chicago, pp. 184-185. 
Vlokh, Mykhaŭlo (ed.) 1970: Vynnyky - Zvenyhorod - Univ ta dovkil'ni sela. Istorychno-memuarnyj zbirnyk. Chicago: Ukrainian Museum of Chicago.

Vovk, Fedir 1908: Antropometrychni doslidy ukraïns'koho naselennia Halychyny, Bukovyny $\breve{1}$ Uhorshchyny. Materiïaly do ukraïns'ko-rus'koï etnol'ogï X, pp. 1-39.

Vynar, Lyubomyr (ed.) 2001: Lystuvannia Mykhaŭla Hrushevs'koho, T. 2. Kyïv, etc.: UIT.

Wendland, Anna Veronika 2001: Die Russophilen in Galizien: Ukrainische Konservative zwischen Österreich und Rußland, 1848-1915. Wien: Verlag der Österreichischen Akademie der Wissenschaften.

Zahra, Tara 2010: Imagined Noncommunities: National Indifference as a Category of Analysis. Slavic Review 69(1), pp. 93-119.

Zaütseva, Zinaïda I. 2006: Ukeräns'kyi nankovyü rukh. Instytutsional'ni aspekty rozvytku. Kinets' XIX - pochatok XX st. Kyiv: KNEU.

Zalozieckyj, V. (ed.) 1930: Das geistige Leben der Ukraine in Vergangenheit und Gegenwart ("Deutschtum und Ausland", vol. 28/29). Münster: Aschendorffsche Verlagsbuchhandlung.

Zayarnyuk, Andriy 2010: Mapping Identities: The Popular Base of Galician Russophilism in the 1890s. Austrian History Yearbook 41, pp. 117-142. DOI: https://doi.org/10.1017/S0067237809990117.

Zubryts'kyı̆, Mykhaŭlo 2016: Avtobiohrafiia. [In:] id. (ed.): Zibrani tvory i materialy u tr'och tomach, T. 2: Materialy do biohrafii. L'viv: Litopys, pp. 53-101.

Zubryts'kyı̆, Mykhå̆lo (ed.) 2013: Zibrani tvory i materialy u tr'och tomach, T. 1: Nankovy pratsi. L'viv: Litopys.

Zubryts'ky̆, Mykhaŭlo (ed.) 2016: Zibrani tvory i materialy u tr'och tomach, T. 2: Materialy do biohrafii. L’viv: Litopys.

Zubryts'ky̆̌, Mykhaŭlo 1905: Stanovyshche rus'koï zhurnalïstyky suprotyv naukovoï roboty v "Nauk. Tovarystvi im. Shevchenka". Literaturno-Naukovyž Vistnyk T. 31, kn. 7, pp. 71-75.

Zvit dyrektsyï ts. k. akademichnö̈ bimnazyz̈ u L'vovi za shkil'nyí rike 1910/1911. L'viv. 